Mitteilungen der Österreichischen Geographischen Gesellschaft, 161. Jg., S. 117-160

(Annals of the Austrian Geographical Society, Vol. 161, pp. 117-160)

Wien (Vienna) 2019, https://doi.org/10.1553/moegg161s117

\title{
Living THe Urban Cultural Landscapes in The City Centre of CluJ-Napoca / Kolozsvár / KLausenburg, Romania
}

\author{
Zoltan MARoşI, Emanuel-Cristian AdoreAn, Oana-Ramona Ilovan, Viorel GLIGOR, \\ all Cluj-Napoca (Romania), Cristina-Georgiana VoICU, Iași (Romania), Alexandru-Sabin \\ NiCUlA and Maria Eliza DulAmă, both Cluj-Napoca (Romania)*
}

Initial submission / erste Einreichung: 03/2018; revised submission / revidierte Fassung: 01/2019; final acceptance / endgültige Annahme: 04/2019

with 12 figures and 4 tables in the text

\section{CONTENTS}

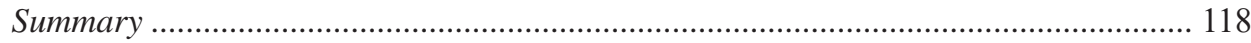

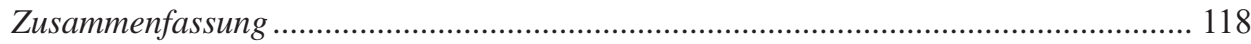

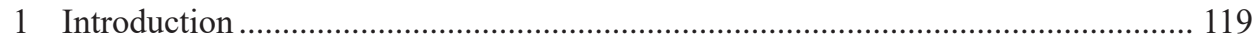

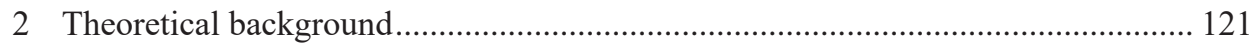

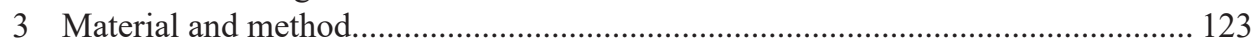

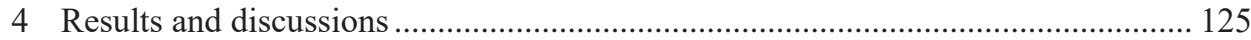

4.1 The past: evolution of the cultural landscape in Cluj-Napoca and the place meanings.......................................................................................... 126

4.2 The present: symbolic and functional public spaces of Cluj-Napoca city centre 129

\footnotetext{
* Zoltan MaroşI, PhD Candidate, Centre for Research on Settlements and Urbanism, Faculty of Geography, Babeş-Bolyai University, Cluj-Napoca, 5-7 Clinicilor St., RO-400006, Romania; - Emanuel-Cristian AdorEAN, MSc, PhD Student, Faculty of Social and Human Sciences, New University of Lisbon \& ISCTE-IUL, Colégio Almada Negreiros, Campus Campolide, PT-1099-085, Lisbon, Portugal, and Faculty of Geography, Babeş-Bolyai University, Cluj-Napoca, 5-7 Clinicilor St., RO-400006, Romania; - Oana-Ramona Ilovan, PhD, Associate Professor (corresponding author), Faculty of Geography, Babeş-Bolyai University Cluj-Napoca, Cluj-Napoca, 5-7 Clinicilor St., RO-400006, Romania; - Viorel GLIGOR, PhD, Lecturer, Faculty of Geography, Babeş-Bolyai University Cluj-Napoca, Cluj-Napoca, 5-7 Clinicilor St., RO-400006, Romania; - Cristina-Georgiana VoICU, PhD, Romanian Geographical Society, Iași Subsidiary, Iași, Carol 1 Blvd., no 20A, RO-700505, Romania; Alexandru-Sabin Nicula, PhD Candidate, Research Assistant, Centre for Research on Settlements and Urbanism, Faculty of Geography, „Babeş-Bolyai” University, Cluj-Napoca, 5-7 Clinicilor St., RO-400006, Romania, and National Institute for Economic Research "Costin C. Kiriţescu”, Romanian Academy, Bucharest, Casa Academiei Române, 13 Septembrie St., no. 13, RO-05071; - Maria Eliza DulAMĂ, PhD, Professor, Faculty of Psychology and Sciences of Education, Babeş-Bolyai University Cluj-Napoca, Cluj-Napoca, 7 Sindicatelor St., RO-400029, Romania. - Emails: zoltan_marosi@yahoo.de, adorean.ec@gmail.com, ilovanoana@yahoo.com, viorel.gligor@ubbcluj.ro, voicucristina2004@yahoo.fr, sabin.nicula@gmail.com,dulama@upcmail.ro.
}

All authors contributed equally to this paper. 
4.3 The future: outlining the dysfunctions of Cluj-Napoca's central squares and interventions towards preserving and promoting the cultural landscapes......... 150

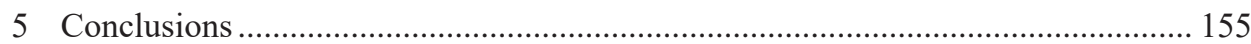

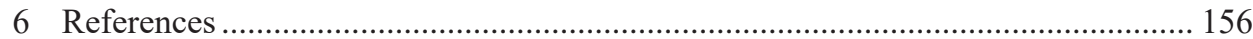

\section{Summary}

More than ever before, today's cities are significantly multi-cultural and heterogeneous. Intrinsically, the modern city centre is the most easily recognisable urban area by both locals and visitors or tourists, due to a concentration of significant functions. In this paper, we discuss the physical and historic centre of Cluj-Napoca, the place that exhibits distinctive structural and functional features and which, throughout history, was shaped and adapted to different ages and needs. As a result, it is the most refined and monumental cultural landscape, granting the city a strong identity and a space rich in cultural significances. Analysing the cultural landscape of these spaces from a past, present and future perspective, it is necessary to emphasise the link between the users' perception of the city centre and the "cold demarcation", through official urban planning, based mainly on quantitative data and on urban indicators (e.g. consistency of the built space, buildings height, proportion between inhabited space and the organised one, accessibility, urban connectivity, etc.). Quite a lot of times, urban planning ignores users'perceptions, being focused on businesses and ensuring people's daily needs and not necessarily on preserving or creating symbolic places, which inhabitants are attached to and where they feel "at home".

Therefore, our aim is to highlight the cultural significance of the public spaces within the city centre of Cluj-Napoca and to assess users' perceptions of these places more and more altered and affected by globalisation spaces. We used the results of two questionnaire surveys and of an extensive research on the history and present features of these spaces. The first survey consisted of 150 filled-in questionnaires designed to set the perceived limits of Cluj-Napoca central area and, the second one, with 300 filled-in questionnaires, aimed to establish the inhabitants' perceptions of the public squares'aesthetics and functionality. Many cities are part of or head towards the so-called cultural vacuum, mainly a result of a profound globalisation and of interpreting culture itself in a wrong way. One more reason for such research approaches to be welcomed and up to date.

Keywords: Cultural landscapes, public spaces, central area, spatial identity, functionality, hybrid places

\section{Zusammenfassung}

\section{Die urbane Kulturlandschaft im Stadtzentrum von Cluj-Napoca / KolozSVÁR / KLAUSENBURG, RumÄNIEN}

Mehr denn je sind die heutigen Städte ausgesprochen multikulturell und heterogen. Dem Zentrum einer modernen Stadt wird angesichts der Konzentration wichtiger Funktionen 
in diesem Bereich sowohl von der einheimischen Bevölkerung als auch von den Besuchern und Touristen am meisten Beachtung geschenkt. Dieser Artikel bezieht sich auf das physische und historische Zentrum von Cluj-Napoca, jenen Stadtteil, der ausgeprägte strukturelle und funktionale Merkmale aufweist und der im Lauf der Zeit in verschiedenen Epochen und durch unterschiedliche und sich wandelnde Bedürfnisse geformt und angepasst wurde und heute eine urbane Kulturlandschaft mit monumentalem Charakter darstellt, der Stadt eine starke Identität verleiht und reich an kulturellem Erbe ist. Durch die Analyse der Kulturlandschaft aus historischer Perspektive sowie in Bezug auf die aktuelle Situation und zukünftige Entwicklungen wird der Zusammenhang zwischen der Wahrnehmung des Stadtzentrums durch die Einwohner und der „,kalten Abgrenzung “ durch die offizielle Stadtplanung, die stärker auf quantitative Daten und städtische Indikatoren setzt (die Dichte der bebauten Fläche, die Höhe der Gebäude, das Verhältnis zwischen bewohnbarem Raum und innerstädtischen Grünflächen, den Zugänglichkeitsgrad, die städtische Verkehrsinfrastruktur usw.) analysiert. In der Stadtplanung wird oft das menschliche ,Wohlfühlen “vernachlässigt, indem man sich eher auf das ökonomische Umfeld konzentriert und nur die alltäglichen Bedürfnisse der Menschen sicherstellt, aber dabei vergisst, einen Ort zu bewahren oder zu schaffen, der die Bewohner anspricht und ein heimisches Gefühl verleiht.

Unser Ziel ist es daher, die kulturelle Bedeutung zentraler öffentlicher Räume aufzeigen und die Wahrnehmung der Bewohner über die zunehmend von der Globalisierung veränderten und betroffenen Gebiete bewerten zu können, und zwar durch die Ergebnisse einer Umfrage, aber auch durch ausführliche Dokumentation über die Geschichte und Gegenwart dieser Räume. Wir haben zwei Umfragen sowie eine ausführliche Untersuchung der Geschichte und der gegenwärtigen Merkmale des Stadtzentrums durchgeführt. In der ersten Umfrage wurde die Wahrnehmung und Abgrenzung des Zentrums von Cluj-Napoca durch die Bevölkerung ermittelt. Das zweite Fragebogen befasste sich mit der Sichtweise der Bewohner über die Ästhetik und die Funktionalität der öffentlichen Plätze. Durch den technologischen Fortschritt entsteht, wie in zahlreichen Städten bereits beobachtet werden kann, ein sog. , kulturelles Vakuum“ bzw. eine gewisse kulturräumliche Uniformität, die vor allem durch die Auswirkungen und Manifestationen einer ausgeprägten Globalisierung und insbesondere auch durch die Fehlinterpretation von ,, Kultur “ selbst geschaffen wurde. Aus diesem grund erscheint ein derartiger Ansatz, wie er im vorliegenden Beitrag dargestellt wird, aktuell und wichtig.

Schlagwörter: Kulturlandschaft, öffentlicher Raum, Zentrum, räumliche Identität, Funktionalität, hybride Räume

\section{Introduction}

Public space, by excellence, is that area where public life and social communication take place and where the distinct mental images of a certain society are created. The way public space is created, used, and maintained points out the essence and intensity of the connections among society members (MAIMUNAH et al. 2015; Mishu et al. 2014; NARCiso 2009; 
Pailliart 2002; Sharma 2014). Nevertheless, nowadays public space does not have the same function as before. Online socialising networks, internet and large commercial areas have taken over an important part of the society from the city streets and squares. Still, public spaces are representative for urban life, as long as the quality of life in cities can be assessed through the size and diversity of the collective life represented in public spaces by parks, squares, and streets. How these spaces are maintained and used also reveals important clues about social mechanisms and studying the citizens' quality of life parallel with the added value of the spaces. Along with other factors taken into consideration, such as the traffic issue related to the inhabitants' sense of security or perceptions of space, smart solutions in urban planning could come out. One of the obstacles of this kind of approach is the high degree of interdisciplinarity and therefore the coordination between different specialists.

Nowadays, one of the biggest challenges that architects, urbanists, urban designers, and territorial analysts are facing is related to the sustainability of public space intervention projects and their contribution to improving the citizens' life quality, as well as the city image (Agachi 2009; Brenner and Schmid 2015; Carmona et al. 2003; Cullen 2010; European Commission 2013; LYNCH 2011; SANDSTRÖM et al. 2006). As a consequence, the management and preservation of local heritage, as well as place identity values are assigned as a relevant facet of urban design and planning.

Cities constantly change. Built heritage, which also entails the inhabitants' symbolic perceptions is the most obvious reflection of this change. The buildings and structures in the city centre convey a story of a meaningful past together, with their cultural values as well. Accordingly, built heritage is supposed to be a specific index of urban identity and thus its preservation is one of the utmost pursuits in urban identity sustainability. Nowadays, cities are growing faster than expected; consequently, the "left empty lands" are rare and valuable. So, urban identity issues bring the question of "what to preserve".

In recent years, we researched the impoverishment of the central public areas of Cluj-Napoca, as a consequence of high-wealth business relocation to the peripheral malls and of a decrease in the use of public spaces for daily or leisure activities, in favour of the online socialising networks (a problem of urban sociology). What are the urban regeneration actions which should be promoted in such a context? And how do the citizens perceive these spaces?

The aim of this paper is to analyse the evolution of Cluj-Napoca's cultural landscapes and its central area in order to identify and research the cultural heritage, the meaning of the place and all the unique features which give a symbolic value to the place and can help to personalise the future development plans and actions. This research will observe the inhabitants' perceptions of the above mentioned issues and will contribute to the local development with tailor made solutions. Several development projects reproduced from the Western and Northern models, although very well intentioned, have failed to meet the local specifications and the national context which is still very different from the developed West. Understanding the history, diversity and originality of the Transylvanian cities is the key to personalised development plans.

Cluj-Napoca, as the administrative centre of Cluj County, is one of the biggest cities of Romania, having more than 320,000 inhabitants, preserving its former function of 
Transylvania's capital and being in direct competition with Bucharest, when it comes to development projects.

The specific research objectives are: (1) aesthetic assessment of urban elements within the "cityscapes" and "streetscapes" of Cluj-Napoca's central open spaces; (2) territorial diagnosis of open public squares in our investigated areas (Museum Square, Union Square, Mihai Viteazul Square, Avram Iancu Square, Ștefan cel Mare Square, and Lucian Blaga Square); (3) underlining the present role of the open public squares in Cluj-Napoca city centre according to their users' perceptions and experiences; (4) identifying regeneration actions that enable both the preservation and improvement of the cultural landscapes of Cluj-Napoca city centre in the context of responsible urban regeneration and increasing attractiveness of this area for its users.

Within this research on the symbolic dimension of the urban functional space, the attention will be devoted to the general context in which this article is outlined, more exactly, in a world characterised by paradoxes, in which the old symbols try to regain their new meanings in a dematerialised urban public space, seeking and generating new meanings and identities for the new urban organism. Given all these, this study seeks to identify the general trends towards which the city centre will be modeled in the near future and also the modernisation projects which will print changes into the urban landscape. In accordance with the changing contemporary society, and with an existing urban framework, already possessing significant values, traditions, and histories, we will analyse the dysfunctions and the authorities' response to them with underway or in progress projects.

The main problems to be discussed are: (1) the degradation (pauperisation) of the historical centre's cultural landscape, (2) the migration of luxury shops from the central area to peripheral malls, (3) degradation of heritage buildings with architectural value through inappropriate use or lack of capital, (4) the problem of traffic congestion and parking spaces and (5) modernisation projects that do not respect the specificity of the place. The structure of this paper, excepting the formal theoretical and methodological parts, will chronologically track the formation of the investigated areas, mainly the central squares of Cluj-Napoca, for a better foundation of today's modernisation actions which in many cases do not correspond to the cultural and historical significances of the place.

\section{Theoretical background}

Our study draws on several concepts, largely debated in the scientific literature during the recent decades: place, authenticity, cultural landscape and public space. These concepts are strongly connected and form the theoretical golden thread of our study. Therefore, we use a selection of theoretical perspectives debating them to create the lens in researching the cultural landscapes of Cluj-Napoca and the role of public squares in their appearance and in building their authenticity. Our endeavour underlines that, in the case of Cluj-Napoca, the historical centre landscape is iconic for the urban image of the entire city.

While trying to entail a paradigm shift in terms of "places connectivity" or a "progressive sense of place" in landscape studies (MASSEY 2008, p. 261), the main focus of this research within urban cultural geography is of a critical reflection which gathers around 
the cityscape change as a spatially and socially contested process, hosting the city metabolism (BUNNELL 2013), both "contemporary as well as historical" (COSGROVE and JACKSON 1987, p. 95).

Within this epistemological and ontological context, modern cultural geographers, such as CRESSWELl (2004), acknowledge the place as a 'meaningful location'. In addition, as a consequence of the "manmade wound in the landscape" (LERNER 2014, p. 78), we witness the emergence of the 'hybrid place' (where both inland and outland coexist), reflecting everyday ways of life, the way people create places, and the progression or life speed over time, while focusing on how the 'new' manifests in the cultural landscape (public monuments or architectural ensembles).

Besides of this new sense of heritage values in the cultural landscape, place making is also involved as a symbol of the growing recognition of the fundamental links between local communities and their heritage, between people and their natural environment (SAUER 2008), being therefore fundamental to people's identity (ZUKIN 2008). In order that all these to be performed, the key towards the ongoing and fast urbanisation process of changing the cultural landscape consists in the concept of authenticity (RIUS-UlLDEMOLINS 2014; GRUBBAUER 2017).

In this regard, this symbolic and functional capability aims at preserving this authenticity by ensuring that all interventions and actions meet the test of authenticity in all respects. Understanding the relative level of heritage resources is essential if we have to rationally determine which elements must be preserved under any circumstance, and which, under special circumstances, will be sacrificed. This level can be measured on the ground of representativeness, rarity, condition, completeness, integrity and interpretive potential of a local resource. At the same time, as a consequence of globalisation, particularly among the younger generations, there is a critical need to pay attention to the warning of the constant threats to this vernacular authenticity.

Closely linked to the process of globalisation, this idea of 'culture as strongly placed' is credited in the cultural studies field by HALL: "When we think of or imagine cultural identity, we tend to 'see' it in a place, in a setting, as part of an imaginary landscape or 'scene'. We give it a background, we put it in a frame, in order to make sense of it" (HALL 2008, p. 268).

Some other theorists as well as urban practitioners attempt to connect the hidden local development identities with the advancement of contemporary urban space (and especially in the case of the present study), which occurs through processes such as: composition / re-composition, association, re-mix, parasitic functional spaces, hybridisation, mutation, aiming to support the emergence of powerful urban landscapes where space specificity and coherence become essential (HĂRMĂNESCU und ENACHE 2016, p. 412).

It is in fact about overlapping two different realities (a functional mixing) as a logical structure and purpose and bringing them to the same denominator despite the clear contrast. The recognition of these 'new places' requires a dynamic perspective - one that emphasises that within these 'synthetic' places, man-made symbols/landscape artifacts (i.e. monuments, statues, squares, all sorts of public spaces and urban amenities, etc.) go beyond the natural ones (i.e. natural landmarks). In other words, this man-made environment (urban space) resides in a 'new landscape', bearing a new 'symbolic value', 
where the aspect of things no longer reveals their precise, authentic nature. The problem of 'placelessness' within cities and the loss of unique sense of place was also debated in older scientific approaches (GALLION and EISNER 1980, p. 395).

Moreover, often, urban spaces are crossroad joints of several paths (LYNCH 1964, qtd. in Moldovan and Purcar 2012, p. 18) regarding the existence of certain "channels along which the observer's movement takes place and these may be streets, alleys, transit lines, canals, and railways". Considering these paths that can be classified in inbound-outbound paths related to the square, and taking into account the most important of these, such as streets and sidewalks as part of the urban texture, one can emphasise the squares' function (of open public spaces), as mobility, transit or leisure areas, respectively (for relaxation, meeting, and public events) (Moldovan and Purcar 2012, p. 18). In the case of public squares, as with public spaces in general, building quality focuses on seven major objectives: living, identity and control, accessing opportunities, imagination, authenticity and significance, community public life, urban self-trust, and adequate atmosphere (VIERO Crestani and Barbosa Filho 2009, p. 2).

According to the present principles of intraurban relation, in Cluj-Napoca the structure of the central public space is polynuclear. It results from the territorial cooperation of several urban segments having distinct functionality and multiple roles: the square as a juncture of two or more routes (Union Square), the square as a juncture of two routes (Avram Iancu Square), the square as a point of inflexion along a route (Mihai Viteazul Square, Lucian Blaga Square), the square as tension release within the urban space and as a "private niche" along a route (Museum Square), and the square as origin/terminus (our classification for Cluj-Napoca, according to the theoretical approach in MoLdovan and PURCAR 2012, pp. 17-41). The next more in-depth analysis is an attempt to underscore the acknowledging role of the symbolic and functional spaces in downtown Cluj-Napoca.

\section{Material and method}

This study presents a new methodological approach, combining quantitative research methods, such as the questionnaire survey and the statistical analysis, with the qualitative ones such as observation, drawing, and thematic photography etc., aiming to collect, represent, analyse and interpret various data which enabled us to analyse the open public space and its users' perceptions of it within the urban public squares of the city centre. The data and methods used in this research involved both a theoretical and empirical approach: the functionality of urban public spaces and their socio-economic transformations as reflected in the present urban cultural landscapes (GEHL and SvARrE 2015; VÂLCEANU et al. 2014).

The methodological frame of this research consisted of three large parts, each with several steps. In the first part of direct observation, information regarding the general features and dysfunctions of Cluj-Napoca central area have been recorded. Building evaluation charts have been completed for each historical building, and photographs were taken for the next step of drawings and indirect observations in the office. Because of the unexpected dysfunctions in the urban landscape and functionality, the main reasearch ob- 
jective has been changed from analysing the conservation of the built heritage and cultural landscape to underlining the present role of Cluj-Napoca central squares according to their users' perceptions and experience.

The second part began with reorganising the roles of each author and involving two recent surveys whose results were not processed at that time. Therefore the second part consisted of processing the questionnaires, drawing, comparing, organising and analysing the data. Mapping the first survey results led to the identification of several interesting links between the commuters' routes, using public transportation and their perception of the central area.

The last part was dedicated exclusively to indirect observation and office work which lasted the most and raised several problems of internal organisation related to the interdisciplinarity of the subject and the desired holistic way of presenting the issues of this research. We have encountered several incompatibilities between the approaches presented in the Western literature regarding our research and the necessities of the Transylvanian cities which were part of many national administrations within the Habsburg Empire, Hungarian Kingdom, Austro-Hungarian Empire and, since 1918, part of Romania (as a monarchy, a socialist republic and a democratic republic). Therefore, our case study required more personalised approaches (SARADJ 2016) and more descriptions, hence the descriptive character of this article.

We conducted two questionnaire surveys: one in April - June 2016 (150 questionnaires), both face-to-face and online, and another one in March and May 2016 (300 valid questionnaires), only face-to-face. The first one aimed at researching the inhabitants' perceptions of spatial limits for Cluj-Napoca city centre, among other issues, and the second one investigated the users' perceptions of the functions and territorial features characteristic to the public squares of this city.

Other methods of collecting field data were direct observation and thematic photography of the objects, objectives and dysfunctions of the investigated area, mapping the area and listing the facilities provided by six central urban squares.

We analysed and mapped in situ and online the buildings height, structure and surface, as well as the whole urban space of Cluj-Napoca city centre (e.g. listing buildings and their height according to 2012 topographic plans and Google Street View, to check the results of our field analysis).

A series of drawings of the architectural cultural landscapes from four of the six explored public squares (Union Square, Museum Square, Mihai Viteazul Square and Avram Iancu Square) and three façades' plans (Union Square, Mihai Viteazul Square and Museum Square) were very useful to understand the features of the urban cultural landscapes. Using sketches or drawings instead of photographs taken by drones in the representation of the investigated public spaces was motivated by the highly selective features of the drawings, allowing the authors to extract and focus on the important information from the rich visual inputs (MAROŞI 2015; 2016).

Besides the fact that they simplify the reality without losing the relevant details, drawings also offer the possibility to introduce the readers to a case study they are not familiar with. We therefore assign the descriptive function to the drawings, while information processing and interpretation should be completed in a productive and solid manner, with- 
out any interruptions. For a clearer spatial representation, the bird's-eye view perspective drawings were employed, due to their characteristics of using the height as a convenient element for an overall and simplified representation of the complex reality (BLAKE 1981).

We also made use of the literature review on the topics of open public spaces and on cultural landscapes to contextualise our research. Here, we underline the following ideas that guided our approach to Cluj-Napoca cultural landscapes. Culture is a rich concept, whose definition was the topic of many large theoretical studies and, therefore, we provide a necessary description of its features that we employed in our study. We considered that culture manifests itself in various forms, while any cultural artefact was analysed according to a three levels approach: (1) denotation of the artefact - description of the visible aspect, (2) connotation of the artefact - interpreting its significances and associating them with other elements, and (3) mythology - which is the most profound way of understanding a cultural artefact, ascribing certain significance to cultural artefacts, which occurs only by associating the individual object with the interpreter's general culture (SCHEIN 1990 qtd. by SPENCER-OATEY 2012, p. 3).

\section{Results and discussions}

The three-part structure of this section is based, as follows, on the chronological order of the factors (past, present, future) that led to the creation of the studied places and their cultural identity. In this way, the first part will focus on a few major historical events relevant to the evolution of Cluj-Napoca cultural landscapes, highlighting not only how the place got its cultural meanings, specificity and significance, but also giving answers for some of the present dysfunctions (such as the degradation of historic buildings, preservation of architectural styles and even traffic problems). Studying the past will also provide the general background information, needed for a further tailor-made research of the present, providing a better understanding of how the city centre was formed and how the normative limits are different from the perceptual limits discussed in the next part. The evolution of the historical centre will be described through the cyclical process of the square's relocation - as place of bargaining and welfare production in the past, in relation to the medieval defensive walls of the town. These two elements have had a major influence on the formation of the current cultural landscape and understanding that the cause-effect relationship is vital for preserving the originality of the place during future interventions.

Based on this local history introduction, the historical centre of Cluj-Napoca - shaped around its squares, will be currently analysed using 'bird's eye view' drawings and maps, showing how this space is perceived by inhabitants, according to the two questionnaire results. The normative limits of the city centre will be compared with its perceptual limits.

The third and last part will focus on the future, outlining certain solutions to the present dysfunctions, implemented projects, cultural landscape transformations, protection of monuments and other recommendations for the future urban planning or urban regeneration of already planned spaces in the past, which today require a functional reconversion to become competitive. The attractiveness and the potential of the centre will be discussed. This last part will also focus on investigating the general features of the 
public space in central Cluj-Napoca, with a thorough analysis of the squares' present features and functions, presenting a typology of the hybrid places and cultural landscapes of Cluj-Napoca.

\subsection{The past: evolution of the cultural landscape in Cluj-Napoca and the place meanings}

Choosing Cluj-Napoca historic centre as a case study is due to its strong cultural identity, expressed through a mixed and unique built heritage which was not destroyed during any of the World Wars. These buildings and generally the entire cultural landscape of the historic centre preserve many layers of history that are highly relevant to Transylvania (as a multicultural region developed under the joint Western and Eastern influences). The open public spaces of Cluj-Napoca historic centre are defined by all the streets, green spaces and historic squares which will be the subject of this study (Fig. 1 and Fig. 3). The city centre rectangular network of streets confers a special look to the urban blocks and is more an original inheritance of the medieval period (although the irregular network was much more common during this period, the colonisations with Saxons in the middle of the $13^{\text {th }}$ century, followed by their specific internal organisation, influenced the formation of rectangular networks) (NIEDERMAIER 2016, pp. 141-142; GALLION and EISNER 1980, pp. 31-35). CIANGĂ (2016, pp. 144-145) considers that "the gates of the fortified cities, by their position inside the defensive walls, usually diametrically opposed, and by their major access function have essentially determined the development of the domestic streets network over time".

The Ancient Roman settlement Municipium Aelium Hadrianum Napoca, that the actual name of Napoca originates (the name was officialised by the State Decree no. 194 of 16 October 1974 in order to emphasise the age and continuity of the Romanian people on these lands; part of the Communist propaganda) (Decree No. 194/1974) had its own defensive walls and structures, but, after the Roman withdrawal, the settlement was gradually abandoned and covered with a thick layer of sediments. According to JAKAB (1870), the memories of the Roman settlement were brutally shattered by Goths, Huns, Gepids, Pechenegs and other nomadic people, in such a way that, from its existence, not even its name can be certainly determined, concluding that "Where memories are silent, the history can't talk" (JAKAB 1870, p. 171). At present, the ruins are excavated punctually and are considered a valuable evidence of the place's history, as a derelict meaningful landscape.

There is no accurate information about the settlement during the Great Migrations period. The ancient name of Napoca has long been lost at the moment of the settlement re-establishment under the new Latin name Clus (JAKAB 1888, pp. 118-120, 146-147). It is worth mentioning that the actual names Cluj, Kolozsvár and Klausenburg derive from the local natural landscape's specificity, as long as Clus (from Latin 'clusa' meaning naturally closed place) has been adapted by the Hungarian population as Clus-vár or Kolozsvár ('vár' in Hungarian meaning stronghold, fortress) and by the Saxon population Cluse-burg, Klausenburg ('burg' in German meaning also castle or citadel) (PASCU 1975, pp. 68-89). 
The $12^{\text {th }}$ century settlement Clus, built over the buried ruins of the ancient settlement (but of smaller size), by reusing the ready to hand source of ancient building materials, had its core in the present Museum Square - the oldest place still in use in the city (NIEDERMAIER 2016, p. 141). The most important event regarding this small prosperous settlement is the Mongol invasion of the Kingdom of Hungary which led to unprecedented destruction all over the kingdom, including the poorly protected Clus. After this dreadful experience, the town was reconstructed, colonised, raised in rank and granted with the rights of building its own fortifications (MACARTNEY 1962, pp. 32-37). Defensive walls made of stone (with many ancient fragments) and a moat were added, the enclosure having an area of approximately five hectares (Fig. 1.1). This first fortified enclosure of Cluj, built in the middle of the $13^{\text {th }}$ century, is still known today as the Old Fortified Town, or in Hungarian 'Óvár', referring to the area around the Museum Square (NIEDERMAIER 2016, pp. 141-142; PASCU 1975, p. 41).

\subsubsection{Urban evolution through cyclical relocation of squares}

The aforementioned settlement Clus has experienced an economic prosperity during the $14^{\text {th }}$ century and the small fortified enclosure had become at a time too cramped and its square (today the Museum Square) too crowded for the periodic fairs. Because of this, the fairs were relocated to the terrain next to the southern gate, on the actual Matei Corvin Street, where the main gate tower and entrance to the Old Fortified Town (the first fortified enclosure) were once located (LuKÁcs 2005, p. 65). On this more spacious terrain, outside the enclosure, a new square was shaping up between the existing roads. This square, known today as Union Square, was originally named the Large Square, to clearly distinguish it from the Small Square - inside the enclosure (Fig. 1.2). This explains why under the northern buildings alignment of Union Square can be discovered as it already happened during restorations, namely parts of the walls from the first fortified enclosure and even remains from the Roman period.

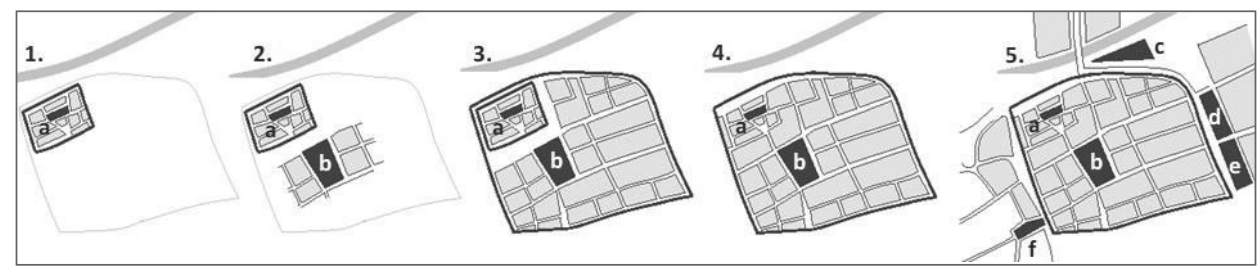

1 - The Old Fortified Town after the Mongol invasion ( $13^{\text {th }}$ century); 2 - The Large Square emergence $\left(14^{\text {th }}\right.$ century); 3 - The second fortification of the town $\left(15^{\text {th }}\right.$ century $) ; \mathbf{4}$ - Agglomeration and further fortification ( $16^{\text {th }}$ century); 5 - Extending beyond the walls ( $17^{\text {th }}$ century).

Squares: a - Museum Square; b - Union Square (Large Square); c - Mihai Viteazul Square; d - Avram Iancu Square; e - Ștefan cel Mare Square; f - Lucian Blaga Square

Source: Drawing by Zoltan MARoşı 2018 C

Figure 1: Cluj-Napoca historic centre evolution around the relocated squares 
Until the $16^{\text {th }}$ century, Union Square was located outside the walls. After another flourishing period, culminating with July 1405, when King Sigismund of Luxembourg ranked Cluj as a Royal Free City (Libera Regia Civitas), the highest city rank in the Kingdom of Hungary, the town also received the right to extend its fortifications to 45 hectares (PASCU 1975 , p. 95). The new fortifications, started as early as the $15^{\text {th }}$ century, had to form an enclosure, so to encompass all the new buildings around Union Square (becoming the new urban core) and also the Old Fortified Town (Fig. 1.3).

Among the third generation of squares, Mihai Viteazul Square (Fig. 8) is of particular relevance in the urban development of Cluj-Napoca because it acknowledges and argues for the progressive pattern based on squares relocation and their key role in the city development. The square developed exactly on the place between the only nearby bridge over Someșul Mic River and the medieval fortress southern gate (Fig. 1.5) and had the function of a cattle market until the beginning of the $19^{\text {th }}$ century (JAKAB 1870, p. 37), the reason why erecting buildings was forbidden, except for wooden households and agricultural outbuildings. A document from 1570 includes the city administration rejection of the requests for building on the land around Mihai Viteazul Square due to the fact that "this external market is always occupied by cattles and the unharnessed horses that bring wood and other commodities to the town" (JAKAB 1888, p. 188; HANTOS 1987, p. 233).

This small detail is of great relevance for the square's urban configuration and cultural landscape, because its rural aspect was preserved until the $18^{\text {th }}$ century, after which the lack of space for development and the emergence of incentives such as the inauguration of the train station in 1870 raised the authorities' and the wealthy investors's attention (RUSU 2015, p. 103). Because the urbanisation was not achieved quickly, the Communist regime continued the process, changing the cultural landscape by inserting the specific Socialist Modernism architecture (which did not affect the former massive intramuros squares).

Going back to the other extramuros squares, we experienced the same cycle, carried out as a new stage of squares relocations, due to the congestion of the second fortified enclosure at the end of the $16^{\text {th }}$ century. During this stage, in addition to Mihai Viteazul Square, Avram Iancu and Lucian Blaga Squares emerged outside the walls. These squares have taken over some of the trade functions of Union Square, always crowded and animated by seasonal, monthly, and weekly fairs. The extramuros squares, situated at the front of the citadel's gates, had the most diverse utilitarian functions: Lucian Blaga Square was the former coal and hay deposit of Cluj during winters, Avram Iancu Square was the former firewood and building materials deposit of the city, but also the place of military training and farmers' fairs until the 1850s (GAAL 2005, p. 95). Constructions near the defensive walls were banned through urban regulations on a distance of 110 meters (RUSU 2015 , p. 88) and only after the walls were dismantled, the area has begun to be occupied by new constructions (aspect still visible in the squares' urban morphology and cultural landscape).

At the begining of the $19^{\text {th }}$ century, the medieval fortifications were affected by severe degradation. After almost a century from the last restoration, the walls became a public danger and a limit to city development. The local authorities decided, despite of the protests, to plot the land occupied by the walls and sell it (SzABó 1946, pp. 15-35). In some cases, the wall (now private property) was demolished and the stone reused although most 
of it has been incorporated into new homes. Almost the entire length of the southern side of the fortification wall still exists today, but it is incorporated into private constructions, as can be seen directly in the street. All the gate towers were demolished, the last of them in 1868, but not before the chief architect of the city (Lajos Pákey) made accurate drawings (MARoşi 2016, p. 52). The building material resulting from the demolition of the towers was used in the building of the great administrative palaces from the eastern side of Avram Iancu Square (Fig. 10) (SzABÓ 1946, pp. 34, 44, 70, 71-72). The created space gave the opportunity to rethink the squares.

\subsection{The present: symbolic and functional public spaces of Cluj-Napoca city centre}

Recent studies showed the necessity of analysing both the urban endogenous asset and its spatial and functional structure for further development (KORCELLI-OLEJNICZAK 2015), while underlining useful approaches in studying space-related perceptions (BLÁHA and NovíčEK 2016). Therefore, considering the urban evolution, this sub-chapter is focusing on the present, and especially on how the city centre is perceived by the inhabitants, on the quality of life, as well as on the hybrid places and cultural landscapes of this city. The following questions will be answered: (1) how are the boundaries of the historic centre perceived by the inhabitants? (2) to what extent does the perceptual limit overlap the normative limit of the city centre established by urban planning? (3) which are the functional and aesthetic features of the historic squares today? and (4) are the hybrid places and cultural landscapes of this city attractive enough for future commercial and tourist developments?

\subsubsection{Historical, administrative and perceptive limits of Cluj-Napoca central area}

The socio-cultural influences that the city of Cluj-Napoca has gathered over time are reflected in its current urban morphology and in the emergence of distinct sub-zones within the historic city centre, separated on urban plans by the medieval fortifications. In the official General Urban Plan, the city centre covers two subcategories of zones: (1) the central zone, overlapping the former fortified enclosure, and (2) the central zone outside the fortified enclosure (PETRINA 2014), which also includes the extramuros squares.

In order to achieve a relational analysis between the official limits of the central zone and its population's perceptual limits, a questionnaire was administered to a sample of 150 respondents who were asked an open-ended question: "Which are the limits of the city centre from your perspective?"

Of those 150 self-administered filled-in questionnaires, spread in both hardcopy and online version, only 93 responses were validated, a response rate of 62 percent respectively. Most of the responses were given by employees (teachers, engineers, counsellors, economists, and civil servants), with an average age of 35 years. Their answers generally included street names, but they also resorted to the use of local landmarks, such as government buildings, or even names of public transport stations. All the responses have been processed in a way to define an area bounded by the aforementioned references; the process also required data interpolation. 
Drawing each limit by a georeferencing QGIS programme was necessary for a visual representation of the database. By overlapping them, we wanted to generate the population's perceptual limit of the city centre and hence the opportunity to compare the result with the official or normative limit of the urban plan. However, while processing the questionnaire data, a wide variety of responses hampered our interpretation and therefore we decided to group the responses into four categories, depending on the extension of perceptual limits in the north-south and west-east cardinal directions and to draw them in AutoCAD 2015 (Fig. 2).

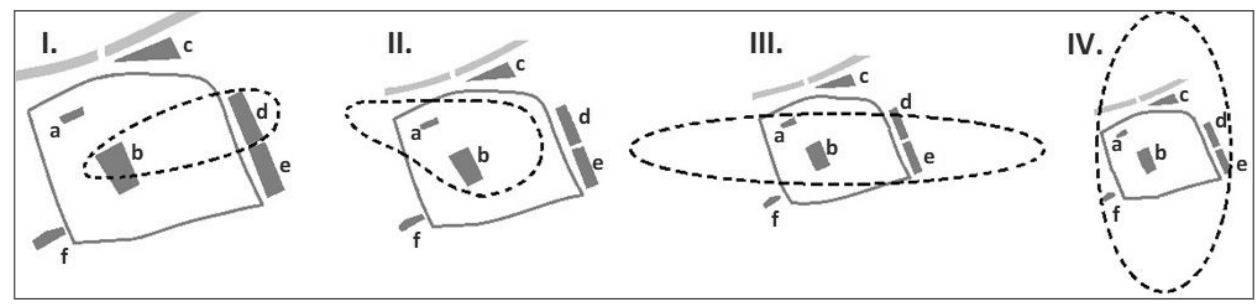

I - The first category, in which the perceptual limits are smaller than the former fortified enclosure; II - The second category, in which the perceptual limits are almost equal to the official limits; III - The third category, in which the perceptual limits far exceed the official limits in the west-east direction; IV - The fourth category, in which the perceptual limits far exceed the official limits in the north-south direction

Squares: a - Museum Square; b - Union Square; c - Mihai Viteazul Square; d - Avram Iancu Square; e - Ștefan cel Mare Square; f - Lucian Blaga Square

Source: Drawing by Zoltan Maroşı 2018 C

Figure 2: Categories of the population's perceptual limits of the city centre

The first category of limits (Fig. 2.I) covered only a small part of the former fortified enclosure, generally focusing on the central squares, as follows: Union Square, Avram Iancu Square and their interconnected boulevard sections. A total of 27 responses ( 29 percent) fit in the first category. This category of perceptual limits is covering only a half of the former fortified enclosure (and also the official limits of the historic centre). Most of the respondents offering these answers are students, who are not yet familiar with the specifics of the places.

The second category of limits (Fig. 2.II) overlapped the old fortified enclosure, containing the closest answers to the normative limit, to which a small westward extension to the Central Park was added. In this category, 20 responses (22 percent) do not exceed the limits of the fortified enclosure, while another 10 responses (11 percent) are extending their limit to the Central Park. Generally, civil servants and those who are aware of the place's history gave these answers.

The third category (Fig. 2.III) exceeds considerably the normative limit of the city centre and it consists of 28 responses ( 39 percent). The main feature of this category is given by the expansion of the perceptual city centre to the west-east direction, along major public transport lines, linking two major residential city districts: Mănăștur District, locat- 
ed on the west side of the historic centre, and Mărăşti District, settled on the east side. Of these 28 responses, 12 respondents included the total area between these two districts in their perceived city centre.

The fourth category (Fig. 2.IV) consists of stretched-out limits influenced by major public transport lines, this time on north-south direction, including only 8 responses $(9$ percent), but of great relevance given that almost all respondents in this category have their permanent or temporary residence in Zorilor District, located on the southern side of the city. These respondents use the bus line connecting Zorilor District to the Railway Station Square on the northern side of the city in their daily commuting.

To support the major impact of public transport lines on the population's perceptual limits of the city centre with arguments, we stressed that Museum Square, one of the oldest squares of Cluj-Napoca, being the urban core, was very rarely mentioned by the respondents because of the hidden space between the buildings, crossed only by pedestrian paths and with no connection to public transport stations in the closest vicinity (Fig. 3).

The limits of the city centre are rather flexible if we take into account the public space users' perceptions. The comparative analysis of the results highlights the fact that the answers vary greatly from the official limit of the central area, far exceeding it or being limited to the central squares only. The most commonly mentioned answers were Union Square, Avram Iancu Square, and the connections among them.

These responses have been distorted at a perceptual level from three considerations: a) when referring to the city centre, the respondents tend to locate it punctually; b) in many cases, the perceptual city centre was heavily distorted on the north-south and westeast cardinal transport axes; c) distortions of the perceived limits can also be explained by the development of the built-up areas and especially by the emergence of new polarising commercial centres, such as shopping malls, in the districts adjacent to the central areas.

However, the perception of the city centre beyond its normative limits is due, as already mentioned, to the major public transport lines used by respondents in their commuting from different residential districts to the workplaces. Associating the answers with the respondents' home address and also with the main public transport lines they used, led to the observation of how their perception of the city centre is influenced. For instance, a respondent who lives in Zorilor District and who mostly uses the bus line 35 (Zorilor District to the Railway Station Square) would consider the limits of the city centre closer to him or her and thus an elongated shape, which is noticeably different from the more compact normative limit, arises. This could also be due to the fact that they are more familiar with the names of the streets and landmarks closer to their residence. As such, the lack of mentions regarding those 'hidden' central areas such as Museum Square and streets that are not crossed by public transport lines can be explained.

The same phenomenon occurs in the third category of responses, mostly given by the respondents having their residential area in one of the two largest districts: Mănăştur and Mărăști, located west and east from Cluj-Napoca historic centre, who generally use the bus line 25 to cross the city centre from one side to another. Their feedback mainly contained street names which had a public transport station with the same name (e.g. 


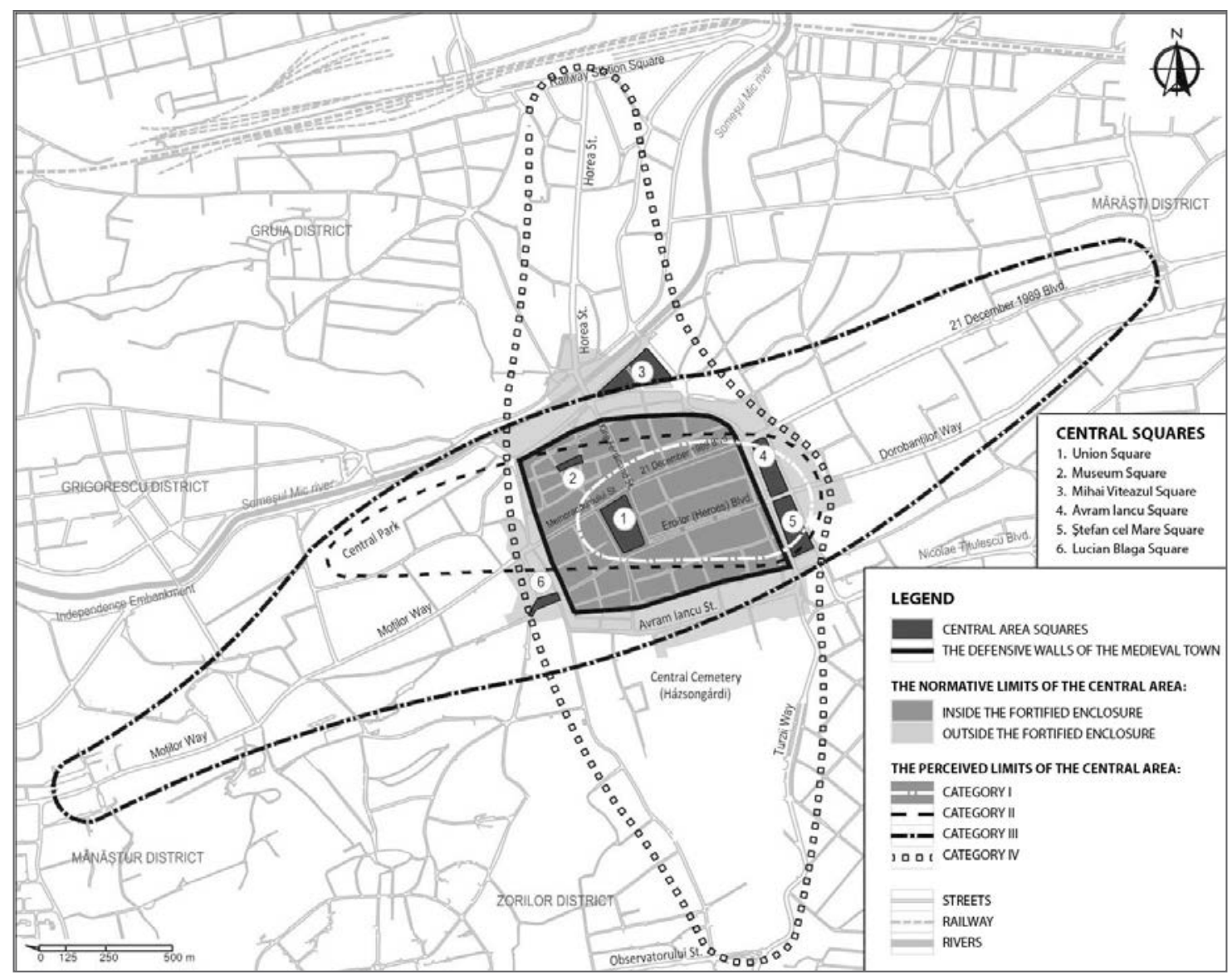

Source: Cartography by Zoltan Maroşı 2018 C

Figure 3: Historical, administrative and perceptive limits of downtown Cluj-Napoca: walling in or walling out inhabitants' perceptions

Memorandumului), which further strengthens our observations regarding the influences of public transportation.

While researching the perception of the public squares' aesthetics and functionality, we conducted a second survey and thus administered 300 face to face questionnaires on the investigated public squares, in March and May 2016. The characteristics of the surveyed sample (Table 1) emphasise the centripetal nature of the city, with a stress on the ethnic, social, cultural, and behavioural heterogeneity at the same time.

The recreational function could be considered the most significant and common within the central squares of the city, being invoked by 38.33 percent of the respondents as the primary usage of the squares, followed by the cultural one, which was pointed out by 26.66 percent of the sample. In addition, commercial, administrative, religious and sym- 


\begin{tabular}{|c|c|c|c|c|c|c|c|}
\hline Characteristics & \multicolumn{7}{|c|}{ Percentages calculated from the total of 300 respondents } \\
\hline \multirow{2}{*}{ Gender } & \multicolumn{4}{|c|}{ Women } & \multicolumn{3}{|c|}{ Men } \\
\hline & \multicolumn{4}{|c|}{$52.33 \%$} & \multicolumn{3}{|c|}{$47.67 \%$} \\
\hline \multirow{2}{*}{ Age } & 15-25 & $25-35$ & & -45 & 45-55 & $55-65$ & over 65 \\
\hline & $25.33 \%$ & $23.33 \%$ & & $33 \%$ & $12.66 \%$ & $15.66 \%$ & $8.66 \%$ \\
\hline \multirow[t]{2}{*}{ Education level } & Gymnasium & \multicolumn{2}{|c|}{ High School } & \multicolumn{2}{|c|}{ Bachelor's degree } & \multicolumn{2}{|c|}{$\begin{array}{l}\text { Master's degree } \\
\text { and Ph.D. }\end{array}$} \\
\hline & $13 \%$ & \multicolumn{2}{|c|}{$37 \%$} & \multicolumn{2}{|c|}{$38 \%$} & \multicolumn{2}{|c|}{$12 \%$} \\
\hline \multirow{2}{*}{$\begin{array}{l}\text { Occupation and } \\
\text { residence }\end{array}$} & Active & \multicolumn{2}{|c|}{ Inactive } & \multicolumn{2}{|c|}{ Within the city } & \multicolumn{2}{|c|}{ Outside the city } \\
\hline & $70 \%$ & \multicolumn{2}{|c|}{$30 \%$} & \multicolumn{2}{|c|}{$66 \%$} & \multicolumn{2}{|c|}{$34 \%$} \\
\hline \multirow{2}{*}{ Ethnicity } & \multicolumn{2}{|c|}{ Romanian } & & \multicolumn{2}{|c|}{ Hungarian } & \multicolumn{2}{|c|}{ Other } \\
\hline & \multicolumn{2}{|c|}{$83 \%$} & & \multicolumn{2}{|c|}{$12 \%$} & \multicolumn{2}{|c|}{$5 \%$} \\
\hline
\end{tabular}

Table 1: The characteristics of the sample in the second questionnaire survey

bolic functions also recorded significant percentages (in the analysis of the squares, we shall return to the results in detail).

The recreational function was examined as being dominant first in Ștefan cel Mare Square, secondly in Avram Iancu Square and Museum Square, next in Mihai Viteazul Square, in Union Square, and lastly in Lucian Blaga Square, respectively (this hierarchy was made according to the number of answers considering it dominant for each public square). The cultural function is the most representative for Lucian Blaga Square, followed by Union Square, Ștefan cel Mare Square, Museum Square, Avram Iancu Square and Mihai Viteazul Square respectively. Instead, the commercial function is more relevant for Mihai Viteazul Square, followed by Union Square, and Museum Square. On the other hand, the civic function is highly prevalent in case of Union Square, the religious function in Avram Iancu Square, the symbolic function in Mihai Viteazul Square, the aesthetic function in Avram Iancu Square, the historic function in Museum Square, and the transit function in Lucian Blaga Square.

Considering the users' perceptions regarding the green area of each square, 128 people were satisfied, while another 121 people were dissatisfied. Avram Iancu Square is ranked first, with 80 percent of the respondents saying they were satisfied with the green surface. Mihai Viteazul Square ranked second, with 62 percent of the satisfied respondents, next, the filled-in questionnaires confirmed 56 percent of the surveyed users being satisfied with the green surface in Ștefan cel Mare Square; in case of Lucian Blaga Square, 22 percent of respondents declared themselves satisfied with the total surface of green area, and 68 percent unsatisfied and very unsatisfied. Furthermore, Union Square was prevalent for the unsatisfied (44 percent) and very unsatisfied ( 24 percent) users and, finally, according to the answers, Museum Square was the most disadvantaged in terms of green area surface, 78 percent of the surveyed users being unsatisfied and very unsatisfied (the green area issue will be detailed for the analysis of each square in the next parts). 


\subsubsection{Present features of the cultural landscapes of Cluj-Napoca}

The "morphostructural" model of the urban squares which fits our explored territory is part of the cultural landscape representative for the states belonging to the Central European geographical space (e.g. Slovakia, Slovenia, Hungary) characterised by a more "sophisticated" system than those specific to German cities (Constantin 2017, p. 349). At the beginning of the $21^{\text {st }}$ century, the historic centre (formed by the former fortified enclosure and the analysed squares) was the main commercial area of the city, with a wide range of products and services. Starting with Romania's accession to the European Union in 2007, two socio-economic phenomena changed Cluj-Napoca city (PĂCURAR 2013, p. 97). The first was the building of shopping centres at the city's opposite peripheries in 2007 (Polus Centre, recently renamed Vivo, on the west side, and Iulius Mall on the south-eastern side), which attracted the existing commercial activities of the city centre. Simultaneously, the second phenomenon was the establishment of the pedestrian areas, starting with Museum Square and the Heroes Boulevard between 2006 and 2007. The polarising initiative of this pedestrian area in Cluj-Napoca aimed to provide better accessibility and enjoyable ride in the public city centre, to reduce pollution, traffic jam and accidents, and to develop the business environment.

Currently, Cluj-Napoca has about $60,596 \mathrm{~m}^{2}$ of pedestrian and semi-pedestrian areas, all located in the city centre. However, these areas are discontinuous. Five of the six historic squares (except for Lucian Blaga Square) may be regarded as pedestrian (Museum Square) or semi-pedestrian areas (the other four), respectively (see Table 3). Union Square is the largest, with its pedestrian area exceeding $12,000 \mathrm{~m}^{2}$.

Closely linked to the urban public space, there is also a set of cultural, sporting and social events that are mostly organised in the city centre (often in Union Square). Cluj-Napoca quickly grew into an urban pole focused on organising large-scale events. For instance, the city was awarded the title of The European Youth Capital in 2015. The multicultural population of Cluj-Napoca, which contributes to the diversity of organised festivals, must also be mentioned here. The population of Cluj-Napoca sums up 22 different nationalities. Several ethnic minorities have their own festivals, while sharing their culture with other residents. CIANGÁ $(2016$, pp. 64, 163) considers that the most significant element of identity is represented by the multicultural aspect of Cluj-Napoca given by the coexistence of Romanians, Hungarians, Saxons and others and the successful way in which these cohabiting communities have been involved in the city development and in conferring it originality.

It is also worth mentioning its status as a student city and its important youthification in certain areas because of this (COCHECI and MitreA 2018), a phenomenon often closely related to that of the gentrification of the urban central area (ADOREAN et al. 2017). This has a major impact on the development of city festivals, as well as of its culture in general. First of all, the thrilling and dynamic atmosphere of the city is mainly due to the students.

At the end of 2015, Cluj-Napoca had about 10 cycling tracks mainly located in the city centre. Their length does not exceed 7 kilometers, which does not lead to a real urban cycling network (BoLOG and MaTHE 2015, p. 85), even if the number of its users has considerably increased recently. However, taking into account the contemporary 


\begin{tabular}{|c|c|c|c|c|c|c|c|}
\hline \multirow[b]{2}{*}{$\begin{array}{l}\text { Central } \\
\text { Squares }\end{array}$} & \multicolumn{6}{|c|}{ Urban furniture } & \multirow[b]{2}{*}{$\begin{array}{l}\text { Special } \\
\text { features }\end{array}$} \\
\hline & $\begin{array}{l}\text { Ben- } \\
\text { ches }\end{array}$ & $\begin{array}{l}\text { Trash } \\
\text { bins }\end{array}$ & $\begin{array}{l}\text { Infor- } \\
\text { mation } \\
\text { panels }\end{array}$ & $\begin{array}{l}\text { Bicycle } \\
\text { racks }\end{array}$ & $\begin{array}{l}\text { Flag } \\
\text { posts }\end{array}$ & $\begin{array}{c}\text { Flower } \\
\text { boxes }\end{array}$ & \\
\hline Union Square & $42+9$ & 28 & 3 & 1 & 10 & $15+6$ & ice skating ring \\
\hline $\begin{array}{l}\text { Museum } \\
\text { Square }\end{array}$ & 11 & 6 & - & 1 & - & 3 & \\
\hline $\begin{array}{l}\text { Mihai Viteazul } \\
\text { Square }\end{array}$ & 24 & 19 & - & - & 1 & 20 & 3 ticket stands \\
\hline $\begin{array}{l}\text { Avram Iancu } \\
\text { Square }\end{array}$ & 26 & 22 & 5 & - & 45 & 12 & \\
\hline $\begin{array}{l}\text { Ştefan cel } \\
\text { Mare Square }\end{array}$ & 44 & 42 & 1 & 1 & - & 26 & 1 playground \\
\hline $\begin{array}{l}\text { Lucian Blaga } \\
\text { Square }\end{array}$ & 13 & 10 & 2 & 2 & 8 & 14 & 9 florists \\
\hline
\end{tabular}

Table 2: Urban furniture of the public squares in Cluj-Napoca city centre

\begin{tabular}{|c|c|c|c|c|c|c|c|c|c|}
\hline \multirow{2}{*}{$\begin{array}{l}\text { Central } \\
\text { Squares }\end{array}$} & \multirow{2}{*}{$\begin{array}{c}\begin{array}{c}\text { Total } \\
\text { surface* }\end{array} \\
\mathbf{m}^{2} \\
\end{array}$} & \multicolumn{2}{|c|}{$\begin{array}{l}\text { Pedestrian } \\
\text { surface }\end{array}$} & \multicolumn{2}{|c|}{$\begin{array}{c}\text { Road } \\
\text { surface }\end{array}$} & \multicolumn{2}{|c|}{$\begin{array}{l}\text { Green area } \\
\text { surface }\end{array}$} & \multirow{2}{*}{$\begin{array}{l}\stackrel{\dot{\Xi}}{\overline{0}} \\
\%\end{array}$} & \multirow{2}{*}{$\begin{array}{c}\text { Main } \\
\text { functions }\end{array}$} \\
\hline & & $\mathbf{m}^{2}$ & $\%$ & $\mathbf{m}^{2}$ & $\%$ & $\mathbf{m}^{2}$ & $\%$ & & \\
\hline Union Square & 32,000 & 17,000 & 53 & 6,288 & 20 & 4,256 & 13 & 14 & $\begin{array}{l}\text { cultural, } \\
\text { tourist }\end{array}$ \\
\hline $\begin{array}{l}\text { Museum } \\
\text { Square }\end{array}$ & 2,880 & 2,527 & 88 & 128 & 4 & 133 & 5 & 3 & $\begin{array}{l}\text { cultural, } \\
\text { tourist }\end{array}$ \\
\hline $\begin{array}{l}\text { Mihai Viteazul } \\
\text { Square }\end{array}$ & 13,400 & 2,680 & 20 & 5,226 & 39 & 2,144 & 16 & 3 & $\begin{array}{l}\text { commercial, } \\
\text { transit }\end{array}$ \\
\hline $\begin{array}{l}\text { Avram Iancu } \\
\text { Square }\end{array}$ & 24,110 & 4,822 & 20 & 9,991 & 41 & 7,544 & 31 & 7 & $\begin{array}{l}\text { administrative, } \\
\text { religious }\end{array}$ \\
\hline $\begin{array}{l}\text { SStefan cel } \\
\text { Mare Square }\end{array}$ & 29,800 & 9,230 & 31 & 8,640 & 29 & 8,340 & 28 & 12 & $\begin{array}{c}\text { cultural, } \\
\text { recreational }\end{array}$ \\
\hline $\begin{array}{l}\text { Lucian Blaga } \\
\text { Square }\end{array}$ & 5.900 & 2.360 & 40 & 3.068 & 52 & 413 & 7 & 1 & $\begin{array}{c}\text { educational, } \\
\text { medical }\end{array}$ \\
\hline
\end{tabular}

* surface measured on orthophoto maps

Table 3: Territorial balance of the public squares in Cluj-Napoca city centre

European and global trends, the premises of an upward trend are already stated with a major development project of the urban cyclo-tourism system in progress, including the east-west city connection with the metropolitan area of Cluj, of about $60 \mathrm{~km}$ (BoLOG and 
MATHE 2015, p. 85). The public squares of Cluj-Napoca generally evolved from mainly economic functions to new ones - recreational and cultural -, but one may still distinguish among them as they are very heterogeneous as surface, structure, place identity, and leading function.

We noticed that the inhabitants' perceptions regarding the central area differ based on several factors such as home address, routes and means of transport used in daily commute to work and back home, spare time activities and, last but not least, on the characteristics and opportunities provided by this central area.

As previously mentioned, the functions of squares coordinate pedestrian and bicycle flows within the city. However, we must mention that the functions spectrum of each square may not guarantee its functionality as well. A perfect harmony between the sum of the squares' functions, the existing amenities (i.e. street furniture, green areas), and the urban design is required to achieve this (ADOREAN 2016; GHAVAMPOUR 2014).

The current situation emphasises the originality of the squares or, on the contrary, their lack of authenticity. Their symbolism and efficiency will be also emphasised based on the landmark buildings and the urban street furniture (Table 2) inserted in the local urban territorial context.

\subsubsection{Place meanings and cultural landscape of Union Square}

Union Square (in the past Liberty Square, Matthias Corvinus Square or Large Square) has become, through its original features, an identity symbol of Cluj, being dominated by the Roman Catholic St. Michael's Church (built in the Gothic style, between 1316 and 1437, Fig. 4.1) (GRANDPIERRE 1987, pp. 384-388) and the noble palaces with a wide variety of architectural styles and a rich history. The buildings and, above all, St. Michael's Church kept the traces of the city's time and space stages, which is why we see the entire square ensemble as an inseparable architectural-urban conglomerate. In terms of adopted styles and shape, each building is influenced by the adjacent structures, and its central position changed the square into the district of Cluj aristocracy (GAaL 2005, pp. 18-26) (Fig. 4). Today it is the place where many Transylvanian and Hungarian personalities lived, fact also reflected by the name of the buildings (Fig. 5).

The current landscape of the square was preserved as an urban brand and an iconic place of the city, being the first introduced landscape and its image being related to Cluj-Napoca by the inhabitants.

The cultural significance of the square became even greater as the history of the Transylvanian Principality was linked to it, being the place where the governors' palace was built and where many significant figures in history (e.g. Báthory Zsigmond, Rákóczi Zsigmond, Báthory Gábor, Bethlen Gábor) were hosted, crowned or executed (GAAL 2005, p. 8). It was also the place of important events like the religious reforms and counter-reforms, proclamations and propaganda over the centuries. At present, the place still hosts the most important events (i.e. the city's days, concerts, thematic fairs, etc.).

In 1790, the seat of the Transylvanian government (Gubernium) was moved to Cluj and this city became the permanent residence of the governor and of its noble members. As a result, Banffy Palace was built and, at present, is considered the most significant Ba- 


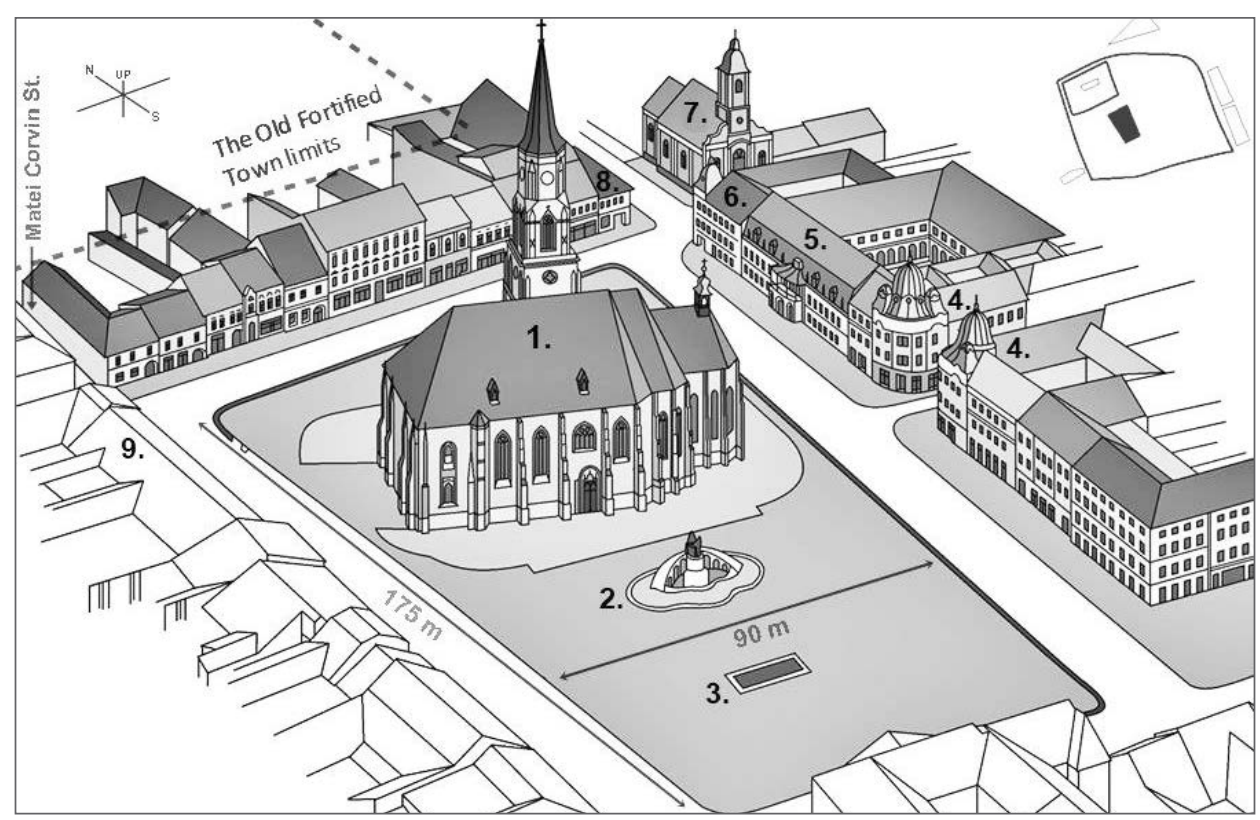

1 - St. Michael's Church (1316); 2 - The statue of Matthias Corvinus (1902); 3 - Ancient Roman ruins (106-275); 4 - The 'twin' buildings of the Roman Catholic Status; 5 - Bánffy Palace (1775), the most important Baroque edifice in Transylvania, today the Museum of Art; 6 - Melody Hotel (1860); 7 - The Evangelical-Lutheran Church (1829); 8 - The Mauksch-Hintz House (15 $5^{\text {th }}$ century), today the Medicine-Historical Museum; 9 - The Roman Catholic Parish (1450), with the inscription that commemorates this building as the temporary residence of Emperor Joseph II, during his visit in 1773 .

\section{Source: Drawing by Zoltan MARoşı 2018 C}

Figure 4: Bird's-eye view drawing of Union Square

roque edifice in Transylvania, being a landmark, as well as a symbol (KELEMEN 1987, pp. 414-416; LUKÁcs 2005, p. 83). Above the balcony, there is the Bánffy family coat of arms and, above and before there was a nine-branched crown, the heraldic symbol of the count's noble title, destroyed in the 1950s (LuKÁcs 2005, pp. 84-85) by the one-party communist rule, during the massive expropriations of the nobles, landowners and of all the Hungarian and Saxon population that supported the Axis in the Second World War.

The Baroque style of the square is still an important part of the actual cultural landscape, but it was made dominant during the Counter-Reformation started after 1699 (The Treaty of Karlowitz), when Transylvania became a principality within the Habsburg Empire (Catholic). At that time, since the Protestant Reformation of the $16^{\text {th }}$ century (when Transylvania was still an autonomous principality), the majority of the population was already converted to Unitarianism (and later to other Protestant religions). Following these major religious reformations, Cluj-Napoca was also the place where the first decrees of religious tolerance in Europe were issued (PoP and Bolovan 2013, pp. 88-90). 
However, during the religious Counter-Reformation, the church architecture became an instrument used to re-establish the Catholic influence, manifested primarily by building the monumental Baroque towers. St. Michael's Gothic Church was adorned with a Baroque tower in 1744, demolished in 1763 because of the earthquake's damage. Despite its short existence, it shows up in two lithographs, being a powerful symbol of the Catholic Counter-Reformation in Transylvania (GRANDPIERRE 1987, p. 386; MARoşI 2016, p. 50). The Baroque tower of the Franciscan Church (Museum Square, Fig. 6.2), from the same period, is still preserved, being part of the cultural heritage. The actual Neo-Gothic tower of St. Michael's Church (80 metres), finished in 1860, was the highest church tower in Romania, until the completion of the Orthodox Metropolitan Cathedral of Timișoara in 1941, and has remained one of the most iconic symbols of Cluj-Napoca.

An example of the cultural landscape development, directly linked to the private properties of the church, are the "twin" buildings of the Roman Catholic Status (Fig. 4.4), built on the eastern alignment of Union Square, on land provided by the city officials, replacing the unaesthetic market buildings surrounding St. Michael's Church (Fig. 4.1) that were rented to merchants during the fairs, by the parish. These structures were demolished as a result of the first large-scale urban planning actions in Cluj-Napoca (NIEDERMAIER 2016, pp. 537-538).

The square also hosts important architectural features giving more meaning to the landscape, starting with one of the oldest buildings, still in use, in the city (besides the church): the headquarters of the Roman-Catholic Archpriestship and St. Michael's Church Parish, also known as the Schleunig House (Fig. 4.9), a historic and architectural monument in Renaissance style. The building bears the name of Schleunig Gergely, who was a priest of the city between 1450 and 1481 and built the foundation of the edifice (GAAL 2005, p. 7).

Among other superlatives, we mention the Bánffy Palace (Fig. 4.5), which is considered "the most important laic monument of the Baroque Cluj and one of the most significant and valuable of the entire urban architecture in Transylvania" (PASCU 1975, p. 251), as the most representative Baroque building in Transylvania.

The Matthias Corvinus Monument (Fig. 4.2), which, ever since its 1902 unveiling, has been a recognisable symbol of Cluj-Napoca (PASCU 1975, p. 370), has given the name to the square (Mátyas Király tér), during the Austro-Hungarian administration, and reminds of the historical narratives about the city and the region itself: "The statue of the greatest Renaissance king, in his birth town is comforting, elevating and in complete harmony with the square, the city and the entire Transylvania" (NAGY 1926, p. 28).

Union Square remains, due to its size $(215 \times 150 \mathrm{~m})$, one of the largest squares built during the Middle Ages on the current Romanian territory, "being the largest from the Central and South Eastern European squares at that time" (ANT/NAT 2015, p. 12), testifying the commercial relevance of the place, which had been a centre of salt trade for centuries and also the home to several prosperous guilds (PASCU 1974, p. 123). The same square measured on ortophotoplans, is roughly $32,000 \mathrm{~m}^{2}$ of which more than half is pedestrian surface $\left(17,000 \mathrm{~m}^{2}\right.$, including sidewalks and paved surfaces, Table 3$)$. This large space is regularly occupied by concert stages, ice skating arenas, tents for various events such as book fairs, outdoor cinema projection screens, and many other special installations, depending on the season. 
The streets width was adapted according to the conditions imposed by the commercial functions of the squares, which were the heart of the urban organism in the past. Today, the widths of Eroilor (Heroes) Boulevard and King Ferdinand Street (Fig. 3) vary depending on the distance from the central square. These two have taken over a part of the Union Square's commercial functions and decongested it (NIEDERMAIER 2016, p. 317). As a result, at present, these adjacent streets were formed as extensions that preserve the main architectural characteristics of Union Square.

The Gothic and Neo-Gothic style of St. Michael's Church, dominating the square, and in harmony with other architectural styles like Renaissance, Baroque, Neoclassical, Art Nouveau and the Eclectic, creates an attractive urban environment through which one can feel the long history of the place (GAAL 2005, pp. 18-26).

This architectural mosaic of great value was not destroyed in any of the World Wars, and the landscape was not altered by the Communist regime, making it easily distinguishable through its originality (Fig. 5). Today, Union Square is simply called "The Centre" by many inhabitants and remains the first place memorised by any visitor. The Hungarian population, still uses the older name - The Main Square (in Hungarian, Fö tér). The historic residences, included on the national list of monuments, also preserve their original Hungarian names taken after their first owners (Fig. 5).

The biggest threats in the future remain the lack of preservation and aggressive interventions to redefine the square. Urban regeneration should replace the planning process in such places, respecting the principle of minimum interventions. Another important dysfunction, which is common to the entire city, is the congested traffic. Two major streets linking the residential districts from East and West are transiting the Southern and Northern sides of the square, contributing to air and sound pollution. The parking spaces are almost non-existent compared to the large number of cars, therefore the use of public transport is self-favoured due to its accessibility and speed. Although there have been numerous modernisation initiatives, the buses on important routes are very crowded during peak hours, many people prefering to walk when the distances are acceptable.

This traffic issue contributes to the inhabitants' perception of the cultural landscape, considering that, instead of a quiet atmosphere in the historic centre, they experience the bustle of a crowded and polluted city. Within this context, people are paying attention to the traffic and their safety, rather than to the urban landscape. For instance, many people (during the survey) recognised the stores on the ground floor, but not the facade of the building as a whole.

Besides this, the degradation of buildings also occurs as a general dysfunction, valid for the entire central area, becoming repulsive for the residential function. The square's layout has been changed many times in the last one hundred years, primarily affecting the ratio between pedestrian and green areas. For example, after 2007, the green lawn and the diagonal sidewalks were completely replaced by a pedestrian area which is much more suitable for the square's architecture and also for its decongestion. The success of this new pedestrian area, that has become the favourite place of events, has led to further improvements (e.g. 2016-2017), by increasing its pedestrian area even more.

The urban furniture is modernised, but not in correspondence with the architectural style of the square (Table 2). For example, modernised public lighting with LED tech- 


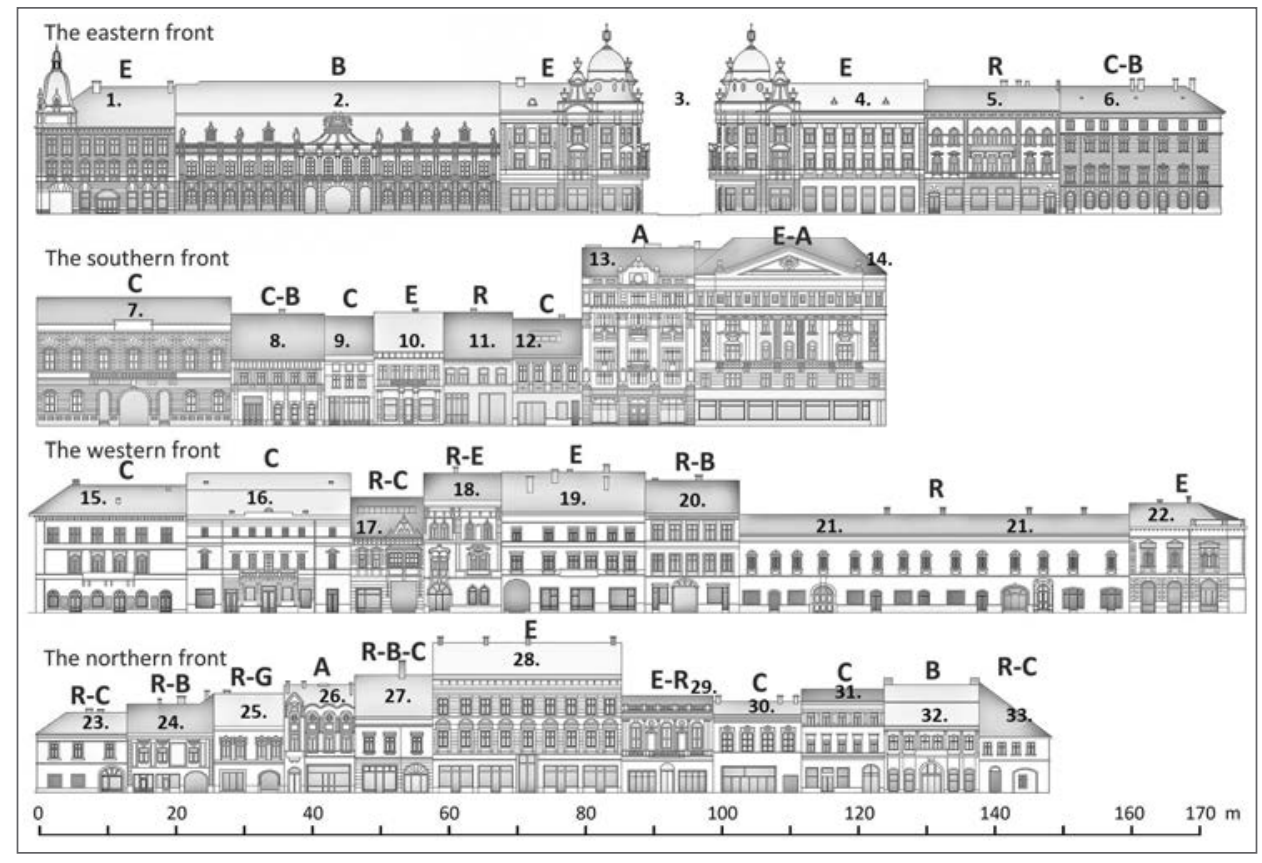

A - Art Nouveau; B - Baroque; C - Classicist; E - Eclectic; G - Gothic; $\mathbf{R}$ - Renaissance.

The name of the buildings: 1 - Hotel Melody; 2 - Bánffy Palace; 3 - The 'twin' buildings; 5 - Wolphard-Kakas; 6 - Pataki-Teleki; 7 - The old town hall; 8 - Simai; 11 - Filstich-Ákontz; 15 - Rhédey Palace; 16 - Jósika Palace; 17 - Wass; 19 - Fröhlich; 20 - Wesselényi; 21 - The Roman Catholic Parish; 24 - Rácz; 25 - Rósás; 32 - Filstich-Kemény; 33 - Mauksch-Hintz.

The ground floor usage: outlets and second-hand clothing shops $(\mathbf{2 3}, \mathbf{3 0}, \mathbf{3 1}, \mathbf{3 3})$; pharmacies $(\mathbf{6}, \mathbf{3 2})$; bakeries, fast-food and pubs $(2, \mathbf{8}, \mathbf{2 4}, \mathbf{2 6})$; restaurants, cafes and ice cream stores $(\mathbf{9}, \mathbf{1 1}, \mathbf{1 5}, \mathbf{1 6}, \mathbf{1 8}$, 20, 21, 30); hotel (1); banks $(5,13,16,21,22,28)$; telecommunication agencies $(4,26)$; spaces for rent $(25,27)$.

Source: Drawings by Zoltan MARoşı 2018 C

Figure 5: Architectural styles of historical buildings in Union Square (LMI 2015)

nology have been installed on all the streets and squares of the central area during 2018, according to the local project funded by the Swiss-Romanian Cooperation Program, Objective 1.4 "Improving the Environment". The new technology is more energy-efficient and with wireless communication components which allows the lighting devices to be programmed for operation at different power levels and on different hourly ranges. However, they do not retain a more classic design suitable for the historic area. Still, the introduction of underground electrical cables (replacing overhead cables) has greatly improved the urban landscape.

Regarding the former function, retail spaces are mostly "clone spaces" (second-hand shops) or "ghost spaces" (edifices temporarily unutilised), which lately have undermined the ideals of this area through their presence. 


\subsubsection{The romantic atmosphere of Museum Square}

The Museum Square (formerly named Carolina Square, Fig. 6) is the oldest place in the city, still in use, and it is regarded at present as a public place with a specific romantic-historical ambience due to its hidden position and its large pedestrian surface ( 88 percent of the square's surface, Table 3). This area is occupied during the warm seasons with chairs, tables and umbrellas belonging to the restaurants' open-air terraces and bars. Most of the time the area is very crowded but still popular among citizens and visitors because there is no traffic and noise pollution as in nearby Union Square. The street that connects Museum Square to Union Square (Matei Corvin Street) is furnished with traditional products and hand-made items stands which are marketed during warm seasons and gives the area an extra aesthetic value.

Today, the historic square encompasses a series of monument-buildings dating back to $16^{\text {th }}-18^{\text {th }}$ centuries, the facades of the old buildings (Fig. 7) hiding multi-century stories (SzABó 1946, pp. 16, 82, 96). The western part of the square hosts the National History Museum of Transylvania, which illustrates the historic evolution and the civilisation of

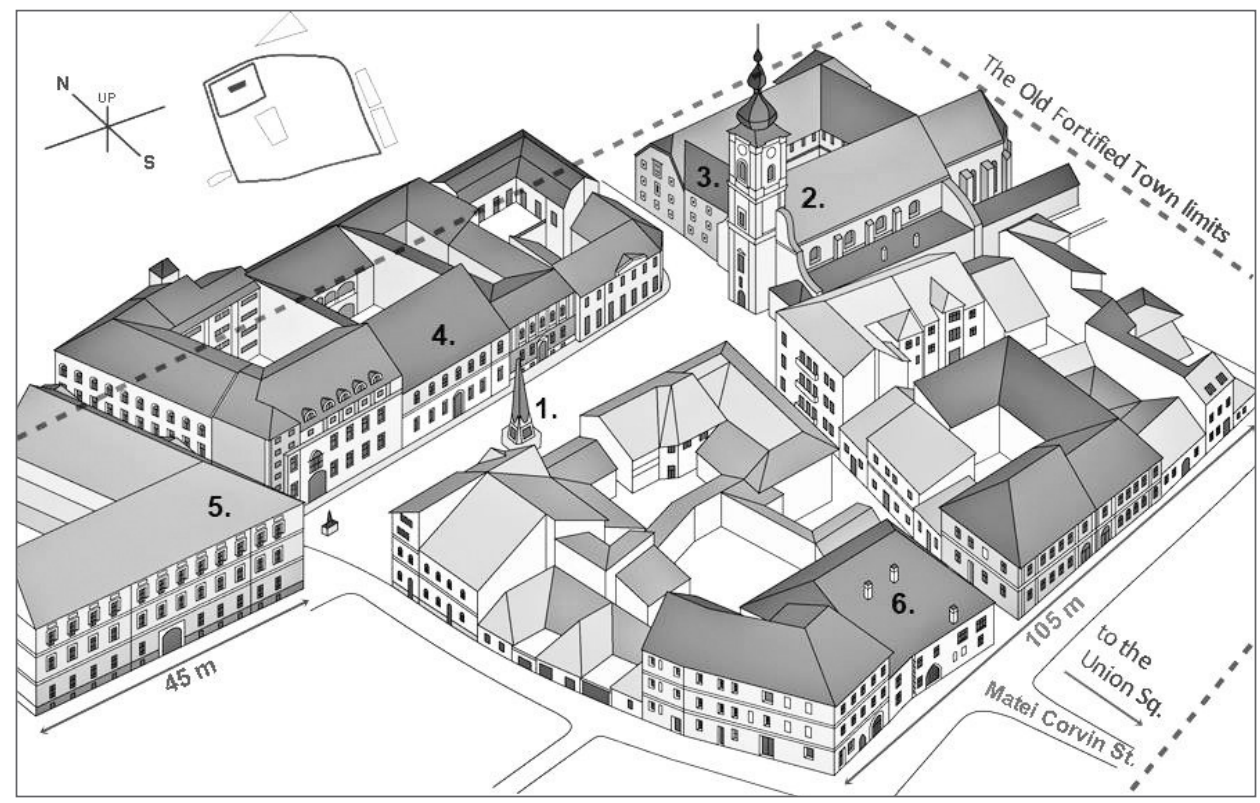

1 - Carolina Obelisk (1831) erected to honour the visit of Empress Caroline Augusta of Bavaria and her husband, Emperor Francis I of Austria (1817) to Cluj; 2 - The Franciscan Church (1260); 3 The Franciscan Abbey (1442), former residence of Queen Isabella of Hungary in 1557; 4 - Mikes House (1846); 5 - Petrechevich-Horváth House, today the National History Museum of Transylvania; 6 - Matthias House ( $15^{\text {th }}$ century), today Ion Andreescu Academy of Visual Arts.

Source: Drawing by Zoltan MARoşı 2016 (C)

Figure 6: Bird's-eye view drawing of Museum Square (Dulamă et al. 2016, p. 70) 
Transylvania (Prehistory, Antiquity, the Middle Ages, and the Modern Era, Fig. 6.5). The eastern side is occupied by the Franciscan Church and Abbey, arguably the oldest buildings, still in use, in the city (DULAMĂ et al. 2016, pp. 73-76; Fig. 6.2), while the surrounding parts of the square host monuments symbolic for the aristocracy of Cluj-Napoca, from different historic periods, such as: Mikes Palace (18 $8^{\text {th }}$ century, Fig. 6.4), Matthias House (15 ${ }^{\text {th }}$ century, Fig. 6.6), Petrechevich-Horvath House, etc. (Fig. 6).

Despite its age, during our surveys regarding the population's perceptions of the central area, the interviewees rarely mentioned Museum Square, somehow due to its hidden location perhaps. The ethnic Hungarian population of the city tends to recognise and identify the square by its old names (Small Square or Carolina Square), due to the presence of two major cultural buildings: the Matthias House, the birthplace of the legendary and very well-known Hungarian King Matthias Corvinus, and the Franciscan Church, with religious services and cultural events in Hungarian.

As the oldest square in the city, here are the oldest buildings and, during restoration works, ruins are often discovered. The area is included in many protected lists of historical monuments and archaeological sites with strict regulations; however, controversial situations arise during new constructions. The architectural styles of the square's buildings are fewer and more modest than those of Union Square, primarily because of its smaller size and because of the numerous changes adopted over the years. Two monumental buildings, having a representative Baroque style (but blended with other styles) are the Franciscan Church and the Mikes House (or Palace) (LMI 2015), which is under renovation for a few years.

The Carolina Obelisk is a symbolic monument of Cluj-Napoca, although only a few people know what it represents and its connection with the place. It was erected to honour the visit of Empress Caroline Augusta of Bavaria and her husband, Emperor Francis I of Austria in 1817 , and the Hungarian population tends to recognise the monument more easily.

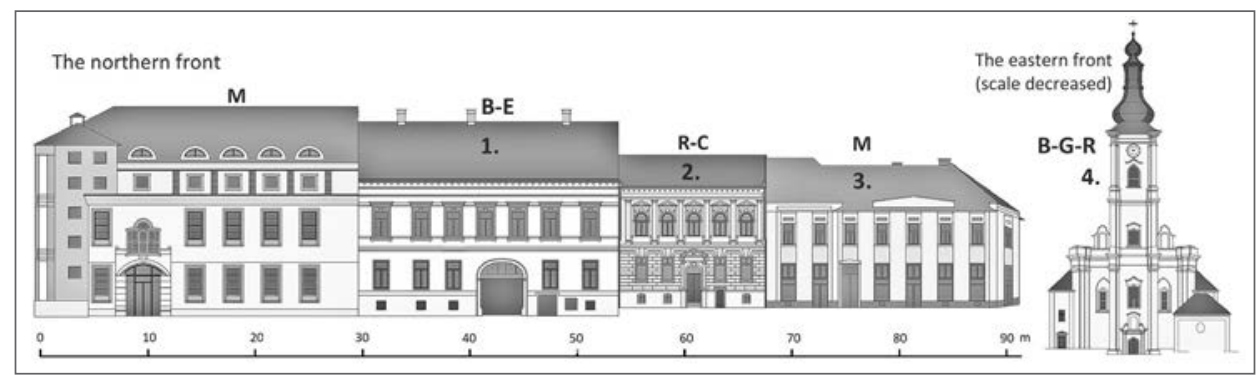

B - Baroque; C - Classicist; E - Eclectic; G - Gothic; R - Renaissance; M - Modernist

The name of the buildings: 1 - Mikes House; 2 - Basta House; $\mathbf{3}$ - The place of the former maternity and the first hospital of Cluj-Napoca visited and sponsored by Empress Caroline Augusta of Bavaria; 4 - The Franciscan Church.

Source: Drawings by Zoltan MARoşı 2016 C)

Figure 7: Architectural styles of the historical buildings in Museum Square (DuLAMĂ et al. 2016, p. 78) 
The biggest dysfunctions of this square are the lack of space (especially during summer, when outdoor terraces are installed) and the poorly maintained buildings which reduce the land value. A better management of space could resolve many problems and also improve the architectural landscape (with a Baroque touch) that is now masked by large trees.

The main functions of the historic buildings define the vibrant atmosphere of the city's nightlife, including retail establishments, food, recreational, cultural, educational, and religious activities.

\subsubsection{Socialist systematisation of Mihai Viteazul and Lucian Blaga Squares}

Mihai Viteazul Square has fewer symbolic edifices compared to the others and is one of the squares that were systematised during the communist period (GAAL 2005, p. 13), as the typical residential blocks with commercial spaces on the ground floor testify.

The railway inauguration in 1870, built to connect Cluj-Napoca and the main Transylvanian cities to Budapest and implicitly to the Austro-Hungarian rail network (PASCU 1975, p. 287), led to a new stage of urbanisation for Horea Street and Mihai Viteazul Square. The main changes to the cultural landscape of the square were the emergence of the four palaces (Babos, Szék, Berde, and Elián Palaces) built after 1890 by business magnates and located on the banks of Someşul Mic, near the bridge (Hantos 1987, p. 233). With the ongoing industrialisation, the space gained a significant upgrade of identity values.

During the late $19^{\text {th }}$ century, Mihai Viteazul Square had the logistics, storage and freight transportation functions within the city, while an urban railway built for this purpose in 1893 became extremely popular due to passenger transportation between the railway station and the Union Square (PASCU 1975, p. 313; ANT/NAT 2015, p. 26). The city industrialisation was a significant turning point in the evolution of the urban landscape, especially through the development of some working class neighbourhoods which contrasted with the nearby tycoons' large palaces. After a series of accidents, the railway, on which the statue of Matthias Corvinus was carried from the railway station to Union Square, was closed in 1902 (PASCU 1975, p. 370). However, it still shows up in various historic photographs. Mihai Viteazul Square became a centre of the bourgeoisie very quickly (LuKÁcs 2005, p. 76).

During the communist regime, major changes were made to the square, the architecture of Socialist Modernism being imposed as a new building style, sometimes even taking into account the demolition of historic buildings (GAAL 2005, pp. 13-14). In the 1950s, the first Communist modern typical blocks were built, primarily as a result of political ideology and the use of architecture to expand its influence and state power (GAAL 2005, p. 13).

The buildings made during this period are distinguished mainly through their flat style, namely their massiveness determined by the extensive control of that political regime and by the extensive use of concrete, demolitions, lack of green spaces, which led to the emergence of so-called 'brutalist' structures (CLEMENT 2012, pp. 3-6; MELVIN 2006, p. 118). These specific buildings stand out in Mihai Viteazul Square and they are often in contrast with the architecture of the interwar period.

The building that dominates the square through its height and massiveness is the 8-storey building on the ground floor of which Florin Piersic cinema is located nowadays, built between 1961 and 1962 (AszTalos 2004, p. 268) (Fig. 8.4). Subsequently, an agro-food 
hall was added and a number of houses were demolished (Fig. 8.5). Mihai Viteazul equestrian statue (the first ruler, as popularised by the communist propaganda, who joined for one year the Romanian historic provinces in 1600; cf. PoP and BOLOVAN 2013, pp. 91-95) is erected in the centre of the square, surrounded by a small green space.

Compared to other historic squares from Cluj-Napoca, Mihai Viteazul Square was one of the most systematised public spaces (aside from the residential neighbourhoods) (cf. Nemeş and Popa 1960) by the Communist Party and it was adapted for the visits of the Romanian dictator Nicolae Ceausescu. One of these visits took place immediately after changing the name of the city, in 1974 (Decree No. 194/1974) (as we mentioned, Napoca was attached to the original name of Cluj, resulting Cluj-Napoca, as part of the Communist propaganda). On the west side, at George Bariţiu Street and King Ferdinand Street crossroad, nearby the bridge over Someşul Mic River, Széky, Berde and Babos Palaces are located (Fig. 8.3), as residences of the late $19^{\text {th }}$ century high-class tycoons, or heritage buildings, which reflect the city's image nowadays.

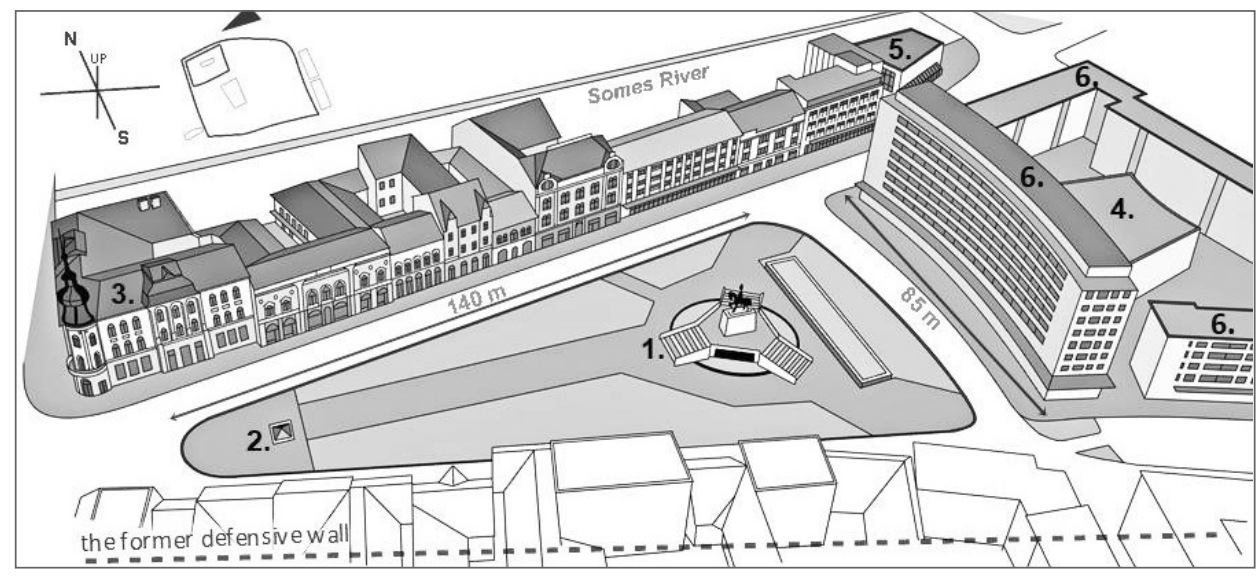

1 - Mihai Viteazul equestrian statue (1976); 2 - The Eternal Flame Monument (2011); 3 - Babos Palace (1890); 4 - Florin Piersic Cinema (1962); 5 - Grocery store (1962); 6 - Residential blocks (1962).

Source: Drawing by Zoltan Maroşı 2018 C)

Figure 8: Bird's-eye view drawing of Mihai Viteazul Square

Communist systematisations played a substantial role as they filled the unstructured spaces with typical residential blocks with large commercial functions on the ground floor, which led to the reconfiguration of the original square function. Many houses belonged to Jewish families, as starting with the 1800 s they had a leading role in the commerce of the city, and Mihai Viteazu Square responded to their expectations, being the place of the first synagogue built in Cluj; but during the Second World War the buildings have been largely emptied or abandoned (GAAL 2005, p. 31). Thus, uninhabited buildings remained as such for a long period of time, giving a shabby look to the square. During the socialist regime, these derelict buildings were demolished and replaced (GAAL 2005, p. 13) (Fig. 9). 


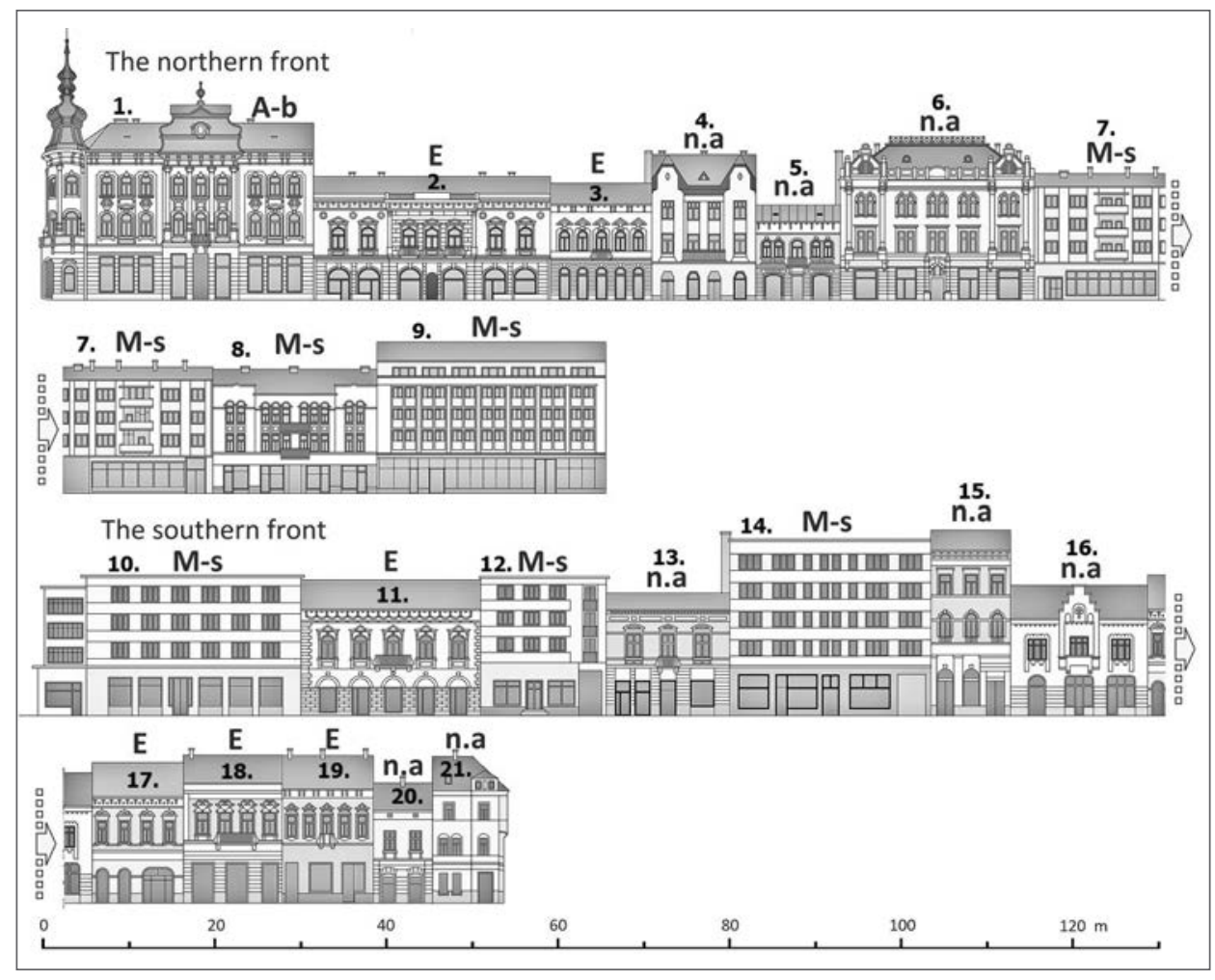

A-b - Art Nouveau (Belle Époque); E - Eclectic; M-s - Socialist modernism; n.a. - not applicable 1 - Babos Palace (1890). The ground floor usage of the buildings: outlets and second-hand clothing shops $(1,2,3,4,5,6,9,11,12,17,18,19)$; pharmacies $(7,13,21)$; medical services $(2,6,9,20)$; bakeries, fast-food and pubs $(3, \mathbf{8}, \mathbf{1 2}, \mathbf{1 4}, \mathbf{2 1})$; banks $(\mathbf{8}, \mathbf{1 7})$; telecommunication agencies $(\mathbf{1 0}, \mathbf{1 5}$, $16)$; betting houses $(9)$; spaces for rent $(3,9)$.

Source: Drawing by Zoltan MARoşı 2018 C

Figure 9: Architectural styles of buildings in Mihai Viteazul Square

The two ticket stands and the automatic ticketing machine for the urban public transport system emphasise the transit and transport functions of the square. The main functions of the buildings outlining the square highlight its features, mostly retail (high presence of "clone spaces", such as second-hand shops), cultural, as well as some food restaurants, recreational, and banking.

Such changes in the urban environment are often due to people's changing lifestyles, which is an essential 'urban ingredient' of identity regeneration. On one hand, we must admit that global brands are all over, not only exhibiting, promoting or selling their products, but they also provide their authentic architectural design or signboards, etc. to wherever they open their branches. One can simply identify a McDonald's restaurant or a multinational branch in any city in the world. What is more worrying is this change of lifestyles and 
thus cultural fusion which global brands bring about. On the other hand, what designates a city lays in its inhabitants' and foreigners' minds. A city's identity resides in what the insiders (inhabitants) and outsiders (foreigners) perceive, experience, and acknowledge about it.

Lucian Blaga Square (formerly Peace Square) is located to the west of the initial basic nucleus of the city, where the old and the new mix up "into an architectural ensemble of $19^{\text {th }}$ century and mid-20 $0^{\text {th }}$ century buildings" (CIORCA 2012). Through the six arterial roads that cross the square, the population's access to various areas of interest within the urban space is allowed. The main symbolic buildings are "Lucian Blaga" Central University Library and the Students' Culture House, having exclusively cultural and educational functions, although "Alexandru Borza" Botanical Gardens and Cluj City Hall are also closely located to the square.

Lucian Blaga Square was formed in the same way, in front of a gateway to the old fortress (for coal and hay storage), although it was not marked by many events. After the construction of the Central University Library between 1906 and 1908, the square received an academic position, reinforced through the construction of the Students' Cultural House in 1960 by the Communist Party (Rusu 2015, p. 41). Near this square was also built the actual City Hall (1897) (LMI 2015).

The main functions of the buildings that integrate the square are cultural, educational, financial-banking, commercial, and residential. Specific to this square is the existence of buildings located apart on the plot, due to the urban tissue fragmentation by arterial roads.

The main activities that take place in this area refer to attending shows, indoor library educational activities, relaxation, socialising, hanging out with friends, waiting, walking, transit, shopping, gastronomic activities, work, and nightlife.

\subsubsection{The Romanian identity of Avram Iancu and Ștefan cel Mare Squares}

Avram Iancu Square (the former Bocskai Square, after 1923 Alexandru I. Cuza Gardens) was originally the wood and timber storage of the city, located outside the walls (RUSU 2015, p. 40). It was also a training field for soldiers, a cattle fair and a park. During the interwar period, after the union of Transylvania with the Kingdom of Romania, the market has undergone numerous changes, primarily of romanisation of the names and buildings. Today it is considered to be the most important square of Cluj, being the place of national celebrations. The cultural landscape is made up of several administrative palaces with Classical architecture built on the eastern side of the square during the Austro-Hungarian period (Fig. 10.4, 10.5), the Lucian Blaga National Theatre (Romanian National Opera, the former Hungarian National Theatre, Fig. 10.1) in a Neo-Baroque style with some Art Nouveau features.

On the western side of the square, on the site of the former fortifications, there are several private buildings with an architectural mosaic. The ground floors of the buildings are occupied by cinemas, bars, clubs, restaurants and small shops, while the floors have a residential or mixed (mainly offices) function.

The Orthodox Cathedral (Fig. 10.3), built with the help of the latest technological innovations between 1921 and 1933, on the land donated by the municipality, has been planned since the beginning to meet all the requirements of the Orthodox rite and to reflect 


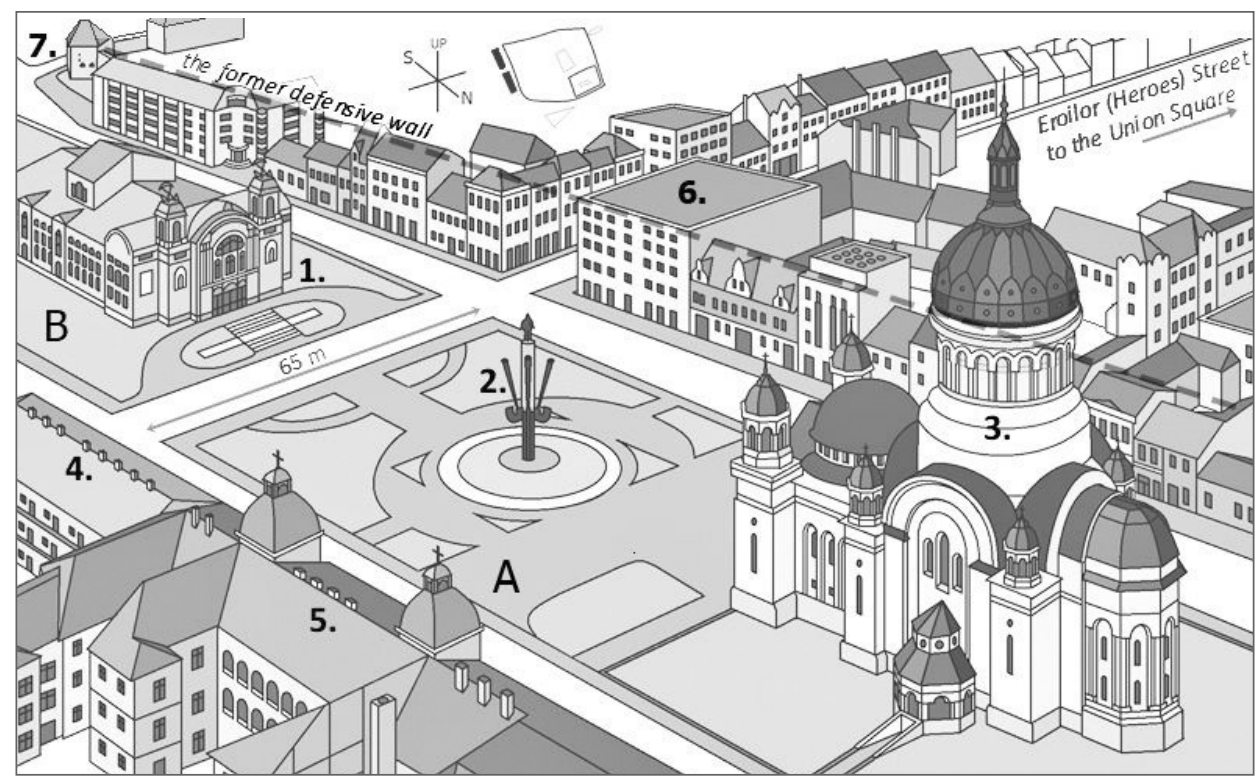

1 - Romanian National Opera of Cluj-Napoca with Art Nouveau architecture (1906); 2 - Statue of Avram Iancu (1993); 3 - Orthodox Cathedral, Cluj-Napoca (1923-1933); 4 - Regional Public Finance Directorate / Palace of Finances with Classical architecture (1880); 5 - Palace of the Orthodox Archdiocese of Cluj, former Austro-Hungarian Headquarters of Forestry Administration (1887) building donated by the Romanian state to the Orthodox Church in 1933; 6 - Cinema Victoria at the ground floor (1931); 7 - Old tower and wall fragment from the former fortifications (The Tailors' Bastion, $15^{\text {th }}$ century).

Source: $\quad$ Drawing by Zoltan MaroşI 2018 C

Figure 10: Bird's-eye view drawing of Avram Iancu (A) and Ștefan cel Mare (B) Squares

as much as possible the virtues of the Romanian style. It was a monumental building with the aim to introduce the Romanian element into the landscape of the Austro-Hungarian city (Rusu 2015, p. 92). The cathedral is still an important symbol of Cluj-Napoca and it is easily recognised by the Orthodox population in Romania. If the Baroque style represented and promoted the Catholic Church during the Counter-Reformation, when all the churches were upgraded with a Baroque style tower, the Byzantine architecture (adapted to the national specificity) became the symbol of Orthodoxy (RUSU 2015, p. 97). The Monument of Avram Iancu (Romanian revolutionary of 1848-1849, Fig. 10.2) was built in 1993 and sparked real controversy among the population and also among intellectuals (RUsu 2015, p. 97) due to its neglected artistic and architectural quality placed on the second place, behind the political implications of the statue.

Ştefan cel Mare Square (formerly known as Ioan de Hunedoara Square) is the Southern extension of Avram Iancu Square. The eastern side of the square hosts the biggest palace of Cluj-Napoca, the Palace of Justice, an eclectic structure, richly decorated, having a surface of $19,950 \mathrm{~m}^{2}$, built between 1898 and 1902. It is the largest of the administrative 
palaces built by the Austro-Hungarians (the Palace of the Railways, the Palace of the Prefecture, the Palace of Finances, the City Hall and the Palace of the Orthodox Archdiocese of Cluj) (GAAL 2005, pp. 95-104).

Even though the landscape elements generated during the Middle Ages are mostly relicts, the old massive fortifications of the city, as well as the influences conveyed by the urban configuration, were mostly preserved (only a few segments of the wall have been restored). Considering this progressive aspect between the ages, Cluj-Napoca urban landscape is a complex example of Transylvanian urban development, reason why the first element of the local identity should be given by the status of historic city (BoGOSAVLIEVICI and ZIMCALĂ 2014, p. 15).

\subsubsection{On hybrid places and cultural landscapes of Cluj-Napoca}

According to planning and landscaping, urban cultural landscapes are more than a mere physiognomy of the built environment. Besides their aesthetic value, they directly influence the formation of a genuine local identity as a significant aspect of the quality of life.

Similarly to cultural landscapes, this local identity is dynamic. The way place (i.e. sense of place, distinctiveness) is experienced has changed. Place and placelessness are intertwined and their relationships have evolved. According to RELPH (2014), Modernist placelessness began after World War II. This Modernist approach in planning and architecture peaked in the West in the 1950s and 1960s, promoting positivism, rationalisation, uniformity (e.g. serried buildings in real estate development, commercial landscape without character, that could be anywhere because of its lack of personality), and efficiency. Placeless elements that are manifest in the Modernist landscape are the asphalt, metal, glass, etc.

The same author underlines that, in the Western World, the 1970s were characterised by an incipient resistance to the promotion and development of placeless landscapes and an advocacy for vernacular architecture. Place is created by using local materials, adjusting what is new or foreign to the local environment and thus resulting in and preserving a local lifestyle. That is why postmodern architecture echoes the vernacular one, focusing on the distinctiveness of places.

Social, technological and philosophical transformations occurred in the last decade and were rendered in the building of a new type of distinctiveness, of the hybrid places and landscapes. Past or the pre-modern authenticity of places is replaced with new features, where the old and new intermingle, creating thus new places and novel experiencing of places: diversity is more and more common. People no longer relate directly to past authenticity, this being pushed to the background, while allowing a juxtaposition of the old and new cultures, of the local and the international, with the occurrence of cosmopolite, multicultural, hybrid places and landscapes - a powerful testimony of the impact of globalisation on the physical and emotional space and memory, on place making. Too much place (i.e. distinctiveness) creates exclusiveness, while sameness may create inclusiveness, by pointing out shared human values and landscapes.

One can distinguish between two types of hybrid cultural landscapes: old and new. We analysed these types in reference to particular places of Cluj-Napoca city centre. The old hybrid cultural landscape (Fig. 11) is represented by associating different urban elements 
of historic value, whose actual use does not fully coincide with the function and specificity of their integrating space (e.g. a multi-levelled old building with ground floor functions that contrast with the typology of their employment conventionality, i.e. second-hand shops, bank headquarters, etc.). This heterogeneous contrasting urban space leads to a disagreeable ('kitsch') look in the current landscape, highlighted by some old buildings with decomposed functions, followed by the disintegration of the urban tissue (daily isolation). According to RELPH (2016) the place identity is intensely related to the authentic sense of place.

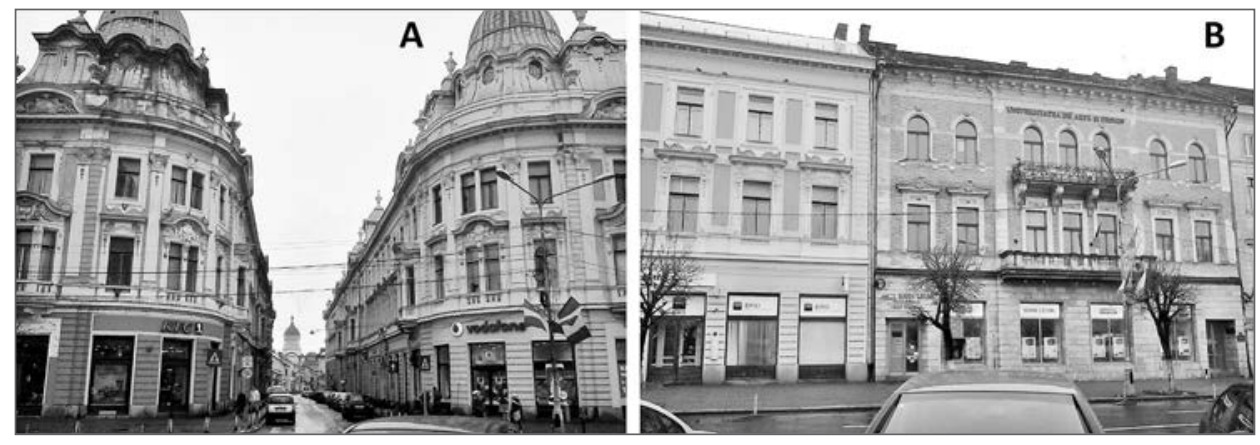

A - Impressive buildings (The 'twin' buildings) with their ground floor rented for commercial activities; B - Historically and architecturally valued buildings, partly used as offices of financial-banking units.

Source: $\quad$ Photos by Zoltan Maroşı, June 2016 C

Figure 11: Old hybrid cultural landscape of Union Square

This sense of place centres on how a person understands a place; hence it requires experience and an individual perspective. Therefore, the structure and qualities of physical elements of the newly shaped urban environment influence the sense of place perceived and rendered by people. RELPH also asserts that disregarding the value/significance devoted to places generates inauthentic places and destroys the authentic ones; he names this change "placelessness" (RELPH 2008).

In case of the newly created hybrid landscape (falsely self-referential, perceived as a form of hybrid cultural identities' representation) (Fig. 12), two elements which generate atypical structural shapes following a postmodernist, hybrid and extremely fast trend are associated: New inserted buildings (to "resuscitate" the old hybrid) and their modern assigned functions (this "self-dissolution" of beautifying the new cultural landscape is what limits any possible connection between the new and the old function of the original place); for instance, building a mall in the city centre, a modern residential complex in a historic urban space, or a sports facility among heritage buildings. In this everyday dwelling, the immersive interface of this new hybrid urban landscape often gives the public space an "urban culture" of fast-food type for the sake of productivity, where the urban identity mixture becomes inevitable. 


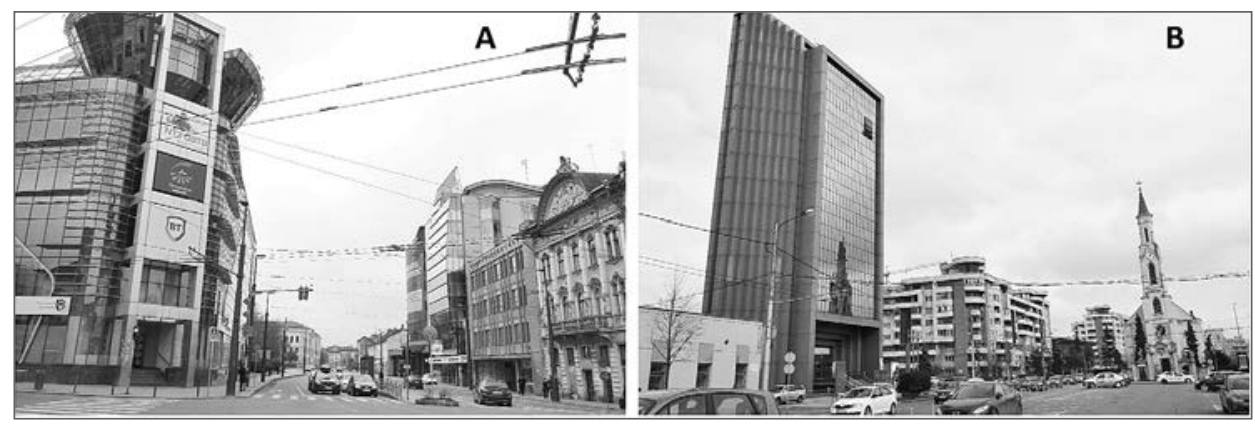

A - Modern offices of financial-banking units inserted among heritage buildings (George Bariţiu Street); B - Urban space overlooked by modern architectural buildings (BDR Group Société Générale headquarters, 21 December 1989 Boulevard)

Source: $\quad$ Photos by Viorel GLigor, February 2018 C

Figure 12: New hybrid cultural landscapes

To go into old buildings, to adapt to the local environment and atmosphere highlights the care for the quality of place, which started to be marketed by the economic sector, while increasingly grasping the importance of place distinctiveness as an asset for their business and giving up building and development of non-places.

To sum up, the subsequent alteration of public space in the city centre of an urban landscape was driven by integrating new (i.e. commercial or entertaining) functions to the former old monument buildings. This concept of urban refashioning/recycling lead to recently developed public places specific to Central Cluj-Napoca as well.

\subsection{The future: outlining the dysfunctions of Cluj-Napoca central squares and in- terventions towards preserving and promoting the cultural landscapes}

The quality of public squares (their features and functions) is a quality of life index in this particular city (GIRото 2013). In Cluj-Napoca, the inauguration of malls and other large commercial areas led to nuclear concentration activities and has emptied the historical centre of high-class commercial activities, with serious consequences upon buildings that had been deprived from systematic maintenance. Instead of a privileged commercial area, the historical centre hosts a growing number of low-class commercial activities which are in contradiction with the theoretical urban land use models (Burgess, Hoyt, Harris and Ullman's, etc.) (GARNER 1972, pp. 303-335), showing an inversion of functions. Second-hand and small outlet stores, grocery stores, fast food restaurants, electronics repair shops, even if they provide a pleasing variety of activities and occupy the free spaces on the ground floor of historical buildings, they do not have the financial strength to maintain the buildings (especially the facades) and thus ghost spaces are formed.

In already reported cases by the local media (Monitorul de Cluj 2015; Radio Cluj 2018), these facades deteriorate until they become a public danger of collapse. In these 
extreme cases, interventions are briefly done by removing the original decorative elements with the risk of collapse, ignoring the historical value of the parts and the possibility of restoration. Owners are usually fined, but this does not bring a solution for the future.

Preventing the decay of Cluj-Napoca old centre supposes adopting medium- and longterm efficient and complex strategies, such as increasing the quality of green areas through a smart design, introducing more urban furniture (e.g. a higher number of benches), creating more pedestrian areas, rehabilitating buildings and historical monuments under a coherent plan to preserve and restore the urban historic centre, regenerating empty buildings and changing some of their functions under landscape regeneration actions, as well as by reconsidering the decorative elements on buildings, their facades colour, public lighting, etc.

The most important elements that influence the urban landscape are the colour of the facades and public lighting, having a direct impact on increasing the landscape value and, indirectly, on increasing commercial activities. From this perspective, many historic centres were regenerated, losing their residential function (mostly insalubrious decaying accommodations) in favour of the commercial one (hosting the headquarters of luxurious companies), leading to exclusively commercial streets, with a wide range of services.

According to GEHL (2011, p. 137), even the physical distance travelled by pedestrians is influenced, to a great extent, by the experienced distance. If pedestrians experience a welcoming urban environment, formed by well-maintained architectural buildings, decorations, public lighting, urban furniture and a quiet and non-aggressive traffic, they tend to walk for longer distances. In most cases, increasing the attractiveness of public squares and of road network connections is achieved by urban regeneration actions, structural and functional reorganisation and higher capitalising of landscape valuable buildings (especially by means of buildings restoration, using decorative elements, and creating pedestrian areas).

The municipality is aware of the major problem of urban traffic and attracted European funds for certain projects, but none of them enough to solve the problems on the long-term. The pleasantness of a place, according to GEHL (2011, p. 171), is primarily influenced by the degree of protection from danger and physical harm, protection from insecurity because of fear of vehicular traffic (but also protection from criminality, unpleasant weather, urban climatic conditions, etc.).

The traffic is an essential condition for the welcoming urban atmosphere. Modernisation of infrastructure and the access routes to the historical centre of Cluj-Napoca was a project which took place between 2014 and 2016, financed through ROP, Priority Axis 1 "Supporting the sustainable development of cities - urban growth poles", and targeted on the restoration of parking lots, bus stops and shelters, sidewalks and green areas on a surface of 20,109 $\mathrm{m}^{2}$, as well as other traffic safety measures, such as signs and markings, vertical signaling and pedestrian traffic measures. The fleet of buses serving the public transportation has been gradually increased, the most recent project and also very popular nationwide was the "Electric buses" Project (2014), through which 11 Solaris electric buses (each 500,000 EUR) were bought and three loading stations have been installed, becoming an important first step towards an environmentally friendly form of transport (Cluj-Napoca also has an extensive system of trolleybuses inherited from the communist period).

In 2015, another project, "Modernization and extension of the public transport system - Stage I (ticketing)", led to upgrading 87 bus stations with benches, trash cans and display 
panels (which will provide information on the time of arrival of each bus at the station) and also installation of 61 automatic tickets machines. All these measures have resulted in more efficiency, but the problem of road traffic in the historical centre of the city has not been solved, this general dysfunction requiring major restructurings and large-scale projects in the near future (Raport de Activitate 2018, p. 21).

\begin{tabular}{|c|c|c|}
\hline $\begin{array}{l}\text { Central } \\
\text { Squares }\end{array}$ & Identified dysfunctions & $\begin{array}{l}\text { Recommended solutions } \\
\text { (for further research) }\end{array}$ \\
\hline \multirow{3}{*}{$\begin{array}{l}\text { Union } \\
\text { Square }\end{array}$} & Heavy traffic, noise and air pollution & Traffic deviation or reduction of speed \\
\hline & Modernization outside the context & Modernization with classic design \\
\hline & Heritage buildings in rapid degradation & Inventorying of degraded buildings \\
\hline \multirow{3}{*}{$\begin{array}{l}\text { Museum } \\
\text { Square }\end{array}$} & Poor management of space & Rethinking local urban regulations \\
\hline & Hidden, unpromoted monuments & Increasing the visibility of monuments \\
\hline & Inadequate urban green-space planning & Green space respecting the Baroque style \\
\hline \multirow{3}{*}{$\begin{array}{l}\text { Mihai } \\
\text { Viteazul } \\
\text { Square }\end{array}$} & Lack of parking spaces and heavy traffic & Underground parking project (in study) \\
\hline & $\begin{array}{l}\text { Requires a bus terminus (too many } \\
\text { stations) }\end{array}$ & Underground bus terminus \\
\hline & The square is isolated by congested roads & Underground pedestrian passage \\
\hline \multirow{3}{*}{$\begin{array}{l}\text { Avram } \\
\text { Iancu } \\
\text { Square }\end{array}$} & Lack of parking spaces and heavy traffic & Traffic deviation or reduction of speed \\
\hline & Functionality problems (unused furniture) & Other functions must be found \\
\hline & Low adaptation to function year-round & Relocation of few events from Union Sq. \\
\hline \multirow{3}{*}{$\begin{array}{c}\text { Ştefan } \\
\text { cel Mare } \\
\text { Square }\end{array}$} & Square without an identity element & Future urban beautification projects \\
\hline & The service area of the National Theater & Other functions must be found \\
\hline & $\begin{array}{l}\text { It is more the Park of the Opera than a } \\
\text { square }\end{array}$ & A future well planned park or a square? \\
\hline \multirow{3}{*}{$\begin{array}{l}\text { Lucian } \\
\text { Blaga } \\
\text { Square }\end{array}$} & Heavy traffic, noise and air pollution & Requiring long-term urban projects \\
\hline & Urban tissue fragmentation by roads & Requiring long-term urban projects \\
\hline & Lack of green space & Planting trees along streets, flower boxes \\
\hline
\end{tabular}

Table 4: Cultural landscapes - outlining the dysfunctions of Cluj-Napoca central squares

\subsubsection{Union Square through restoration projects}

Several projects with reference to the historical centre of Cluj-Napoca, like free wireless internet access, infrastructure modernisation and making public transportation more efficient, have generally improved the quality of life. Among the projects that directly targeted the Union Square is the Rehabilitation of St. Michael's Roman Catholic Church project, started in 2018 and ongoing until 2021. Responsible for this conservation project are St. Michael's Roman Catholic Parish and the City Hall of Cluj-Napoca, the value of the project being 4,700,000 EUR, financed from European funds, through ROP, Priority Axis 5, Investment Priority 5.1. "Preserving, protecting, promoting and developing natural and cultural herit- 
age" (Raport de Activitate 2018, pp. 13-14). The aim of the project is to increase the number of visitors by 6 percent per year and to increase the area's competitiveness.

Although 44 percent of the 300 respondents were unsatisfied with Union Square green area of 4,256 $\mathrm{m}^{2}$ (13 percent of the square surface, see Table 4), it should be mentioned that by increasing the green area (as it was in the past) the pedestrian space, often used for very popular events, would be dramatically reduced. The architectural styles of the buildings (Gothic, Renaissance, Baroque, Neo-Gothic) may fit better with a nice paved square than with a green space; however, ornamental trees and flower boxes are recommended. So it is not about increasing the green space surface, but about increasing the quality of the design.

\subsubsection{Inefficient space management of Museum Square}

The square has benefited from several large projects, but the most visible was the "La pas prin Oraşul Comoară” Project [Walking through the Treasure City] (2010-2013) which aimed at facilitating the access of potential visitors to the information and objectives of interest. During this project, the museums in Cluj-Napoca were promoted and promotional materials were produced (e.g. information boards, brochures, tourist maps, websites, etc.).

The Museum Square does not have a veritable green area, the tree boxes and the small plots occupy only $133 \mathrm{~m}^{2}$ (3 percent of the square surface, Table 4). Because of the lack of space, the tall trees should be relocated. The lack of green area in this square could be easily compensated by the proximity of I. L. Caragiale Park (just 80 meters south of the square). Nevertheless, the respondents' perception should be considered, as 78 percent of the surveyed users were unsatisfied and very unsatisfied, indicating the need of rethinking the green area in a way that did not crowd the space even more.

\subsubsection{Traffic congestion of Mihai Viteazul and Lucian Blaga Squares}

The green area of Mihai Viteazul Square occupies 2,144 $\mathrm{m}^{2}$ (16 percent of the square surface, see Table 4), only half the size of Union Square's green area, but 67 percent of the respondents are satisfied with it. This indicates that the green area surface is not as important as the design. For this square, the future underground projects, such as the planned underground parking space, are more important, as well as a bus terminus which should replace the six stations situated around the square.

Lucian Blaga Square does not have an adequate green area, except the green area around the Central Library, but the streets are occupying 3,068 $\mathrm{m}^{2}$ (52 percent of the square surface, Table 4). Lucian Blaga Square has almost the same traffic issues as Mihai Viteazul Square (except for the public transportation). However, there are no specific projects undertaken or planned for this square. The traffic problems are complex and require particular attention.

\subsubsection{The functionality issue of Avram Iancu and Ștefan cel Mare Squares}

Avram Iancu Square did not require urgent interventions in its design and was not among the priorities of the local government. Yet, all the major projects concerning the historical 
centre of Cluj-Napoca have affected this square. It remains one of the most affected by road traffic, lack of parking spaces, congestion, and noise pollution. Avram Iancu Square is ranked first regarding the users' perceptions of the green area, with 80 percent of the respondents being satisfied. Because the square is mainly used during national holidays and religious events (there are speakers mounted which are functioning during religious services), the year-round function of the square is limited. During the national events of the Great Union Centenary (December 1 ${ }^{\text {st }}, 2018$ ), three new statues of famous religious figures in the history of Romania, were placed in the heart of the square: the statues of Bishop Nicolae Ivan, the statue of Metropolitan Bartolomeu Anania and the statue of Cardinal Iuliu Hossu. These new monuments strengthen the religious function of the square even more, for example, Bartolomeu Anania is also known as the "Lion of Transylvania" for his intransigence and conservatism in the defense of Orthodox values, being one of the outstanding personalities of the Romanian Orthodox Church (Raport de Activitate 2018, p. 71).

Relocating some of the smaller events in this square could resolve many of its functionality problems and would decongest the other squares and would also favour the variety instead of the monotony of the events. The area of the square occupied by streets is $9,991 \mathrm{~m}^{2}$ (or 41 percent of the square surface, Table 4) and is larger than the green area. However, there is still the problem of parking and heavy traffic, being the most congested square of the city.

In order to make this square more attractive, it can be mentioned that the design of details creates the so-called "staying possibilities" in public spaces. For example, the existence of benches, columns, plants, trees, and so forth - and if the facades contain interesting details such as niches, holes, gateways, stairs, etc. - will make it easy to find places to stop. Therefore, "good cities for staying out have irregular facades and a variety of supports in their outdoor spaces" (GEHL 2011, p. 153).

Ștefan cel Mare Square has the largest green area of all the central squares of Cluj, $8,340 \mathrm{~m}^{2}$, and yet it is ranked on the third place by the users' perceptions. Because the National Theater has its facade oriented to Avram Iancu Square, forming its southern side and being more a part of that square, the issue of Ştefan cel Mare Square remains its functionality. Dominated by its green space, known as the Opera Park and in the absence of an identity element (even the square boundaries are questionable and difficult to be identified by the population), this square should be converted into a beautifully landscaped park. The proximity to the preserved medieval fortifications may also influence a functional reconversion of the square, towards an open air urban history park, with an observation point, urban models of the medieval city, maps and informative panels. The large area allows, in the future, many attractive design projects.

As we have already mentioned, Ștefan cel Mare Square has the largest green area among the researched central squares. “Adopt a green space!"-Project (started in 2012) is based on the intention of the municipality of Cluj to collaborate with private economic agents and local institutions, so that the public green areas of the city centre meet the standards of European urban landscape architecture. The adoption of the green area by private agents is done for a minimum of three years with the possibility of extension. In this way, 4,500 $\mathrm{m}^{2}$ green area of Ștefan cel Mare Square (also the Opera Park), 4,700 $\mathrm{m}^{2}$ green 
area of I. L. Caragiale Park (near Museum Square) and $600 \mathrm{~m}^{2}$ of Avram Iancu Square have been included in this programme (Raport de Activitate 2018, p. 25).

Nevertheless, irrespective of their typology, cultural landscapes represent, through their interdisciplinary features, the connection among the branches of Geography and to other kindred fields, that should find together those smart solutions which nowadays' ideas, information, and technology society is based on. By overlapping the specific attributes of physical, social, psychological, and cultural dimensions of each urban space in which we intervene, in a careful multidisciplinary approach, we can find the solutions and the appropriate working tools for the space metamorphoses to be produced not as changes, but as a making/living of places.

\section{Conclusions}

Exploring the changing urban cultural landscape is an intricate topic which results in the intense joint action of people and their built environment. It also requires a social, cultural, psychological, and economic perspective. Therefore, it inherits communities' values, beliefs, lifestyles and symbolic values, which are constructed and change throughout the time. In this paper, we carried out a holistic assessment of the changing cultural landscape of Cluj-Napoca to predict the urban evolutionary direction and the following points were achieved: (1) determining the relevance of urban history in planning and elements of originality that should be distinguished, (2) researching the history of the place and its significance for Transylvania, (3) presenting how the historic squares had acquired their current cultural landscape, (4) how the inhabitants perceived the city centre and the results from comparing the perceived limits with the normative ones, (5) detailed analysis of six of the most important squares of Cluj-Napoca and highlighting their most important dysfunctions, (6) differences between how users perceived the aesthetics and functionality of the squares and official urban management measures, and (7) the future analysed on the basis of the implemented, ongoing and future projects.

This research has included many drawings, pictures and maps, as well as two questionnaire surveys, six inventory readings of urban furniture, hundreds of field observation forms, regulations and official reports, processed by a team of specialised and interdisciplinary authors. Dividing the research into three major parts, focusing on the past present and future, and by observing the field, office and editing stages, this paper also gained an intrinsic methodological value. Among the most surprising results of this research we mention: (I) the way in which the public transport and the daily commuter routes influence the residents' perceptions of the city centre by reducing the commuting time, (II) the differences between the perceived limits of the centre and the official limits, (III) the green area surface of the squares is not directly proportional to the degree of user satisfaction, demonstrating the importance of specialised planning and design and (IV) determining the most important dysfunctions and how the local government responded to them. All these things are reflected, directly or indirectly, in the cultural landscape which is consumed by residents and visitors like any other cultural artifact and increases their quality of life and produces well-being. 
Therefore, the urban planners' concern is how to cope with accentuated urban dynamics and the deterioration of urban identity in today's spontaneous cities, which are more multi-cultural and multi-ethnic than ever before. Hence, urban sustainability should not be curbed to only natural resources, but should also comprise urban identity as cultural heritage. Accordingly, there is a growing demand for research methodologies and evaluation of urban identity. It is what our study highlighted by making the city a place of cultural landscape change and by (re)shaping the city centre of Cluj-Napoca through urban landscape negotiation. We have encouraged the holistic researches and especially the use of history in urban planning, favoring modernisation, but respecting the local context, such as upgrading the lighting system with LED technology, while selecting a classical and matching design in the historic centres, favouring the original at the expense of an universal global design. We have shown that projects isolated from the local context, which do not respect the past, neighbourhood, styles and originality, have no long-term success.

What is even more important is that the essential objective of urban planners and designers nowadays is to build dynamic liveable places for people. Since urban culture is rapidly changing from private to public, challenging lifestyles, this "place liveability" can be decided by people's perceptions of life quality. For this reason, throughout this research, we have respected the perceptions of the inhabitants, who should be increasingly involved in the transformation of the place where they live. The mutual synergy between people and their built environment should be well comprehended and clarified in order to preserve these "liveable places". Unfortunately, it is often too late when we grasp the effects of our actions that caused the loss of urban spatial cohesion. Instead of throwing all the blame on globalisation and urbanisation processes which mutually shaped or "co-produced" new, hybrid cultural landscape, we should also acknowledge that we must devise up-to-date territorial strategies that would redesign the so-called associative cultural landscapes.

The general results presented in this paper will lay the basis for future more detailed researches on the highlighted issues: the congested traffic, the poor management of space, the degradation of historic buildings and monuments, the migration of high-wealth commercial activities to the city's outskirts, in malls, and the impoverishment of the historical centre, noise and air pollution and many other aspects that are reflected in the cultural landscape of Cluj-Napoca. Because the factors and circumstances in which these issues arose are quite particular, urban planning must have a high degree of personalisation, tailored for Cluj-Napoca and not copied from other more developed cities (good practices and methodologies are useful, but they should always be adapted). For this reason, we believe that our paper is a step forward to a more particular planning of the cities, and is a contribution to a more efficient development, respecting the past and ensuring a more sustainable future for next generations.

\section{References}

ANT/NAT (Autoritatea Naţională pentru Turism/National Authority for Tourism) (2015): Piețe istorice şi zone pietonale [Historical Squares and Pedestrian Areas]. - http://turism.gov.ro/ wp-content/uploads/2013/05/brosura-piete-EN.pdf (accessed on June 5, 2016). 
Adorean E.-C. (2016): Designul urban şi funcționalitatea spațiului public central al Municipiului Cluj-Napoca [Urban Design and the Functionality of the Central Public Space in Cluj-Napoca City]. Lucrare de licență [Bachelor's Thesis], Faculty of Geography, Babeș-Bolyai University, Cluj-Napoca.

Adorean E.-C., Ilovan O.-R., Gligor V. (2017): Urban Nightlife Consumption. Case Study: Bairro Alto, Lisbon. In: Territorial Identity and Development, 2 (2), pp. 24-39. - https://doi. org/10.23740/TID220173.

Agachi M. I. M. (22009): Clujul modern. Aspecte urbanistice [Modern Cluj. Urbanistic Aspects]. Cluj-Napoca: U.T. Press.

Asztalos L. (2004): Kolozsvár: helynév- és településtörténeti adattár [Cluj: Place Names and Local History Repository]. Cluj-Napoca: Kolozsvár Társaság.

BláHA J. D., NováčEK A. (2016): How Central Europe Is Perceived and Delimited. In: Mitteilungen der Österreichischen Geographischen Gesellschaft, 158, pp. 193-214.

Blake W. (1981): Landscape Drawing Step by Step. New York: Dover Publications Inc.

Bogosavlievici V. A., Zimcală L. (2014): Clujul văzut și nevăzut. Ghid istorico-turistic [Seen and Unseen Cluj. A Historical-Touristic Guide]. Cluj-Napoca: Editura Mega.

Bolog C., Mathe A. (2015): Îmbinarea realului cu virtualul ca perspectivă pentru dezvoltarea turismului urban în Cluj-Napoca [Mingling the Real with the Virtual as a Perspective on Developing Urban Tourism in Cluj-Napoca]. In: Geographia Napocensis, IX (2), pp. 83-92.

Brenner N., Schmid C. (2015), Towards a New Epistemology of the Urban? In: City, 19 (2-3), pp. 151-182. - https://doi.org/10.1080/13604813.2015.1014712.

Bunnell T. (2013): Urban Landscapes. In: Johnson N. C, Schein R. H., Winders J. (eds.): The Wiley-Blackwell Companion to Cultural Geography. West-Sussex: John Wiley \& Sons, pp. 278-289.

Carmona M., Heath T., Oc T., Tiesdell S. (2003): Public Spaces - Urban Spaces: The Dimensions of Urban Design. Oxford: Architectural Press.

CiangĂ I.-F. (2016): Peisajul urban în vedutismul transilvan [The Urban Landscape in the Transylvanian Vedutism]. Cluj-Napoca: Risoprint.

Ciorca I. (2012): Piaţa Lucian Blaga [Lucian Blaga Square]. - http://www.clujtoday.ro/2012/10/21/ piayua-lucian-blaga.html (accessed on May 10, 2016).

Clement A. (2012): Brutalism: Post-war British Architecture. Ramsbury, Marlborough, Wiltshire: The Crowood Press Ltd.

COCHeci V., Mitrea A. (2018): Youthification in the Metropolitan Area of Cluj. In: Urbanism Architecture Constructions, 9 (2), pp. 121-130.

Constantin D. C. (2017): Orașe în rezumat. Piețele din Europa și istoriile lor [Cities in Summary. European Squares and Their Histories]. București: Editura Universitară "Ion Mincu" \& Editura Peter Pan Art.

Cosgrove D. (1998): Social Formation and Symbolic Landscape. Madison: University of Wisconsin Press.

Cosgrove D., Jackson P. (1987): New Directions in Cultural Geography. In: Area, 19 (2), pp. 95-101.

Cresswell T. (2004): Place: A Short Introduction. Coventry: Blackwell Publishing.

Cullen G. (2010): Paisagem Urbana [Urban Landscape]. Lisboa, Edições 70.

Decree No. 194/1974 privind atribuirea denumirii Cluj-Napoca municipiului Cluj, publicat în Buletinul Oficial al RSR, Nr. 125, vineri, 18 octombrie 1974 [Decree on Changing the Name of Cluj Municipium to Cluj-Napoca]. - https://upload.wikimedia.org/wikipedia/commons/8/8b/Napocirea_Clujului.jpg (accessed on February 5, 2018).

Dulamă M. E., Maroşı Z., Ilovan O.-R. (2016): Chapter 3: Geography University Education for the Protection and Capitalisation of Cultural Urban Landscapes. A Case Study: The Mu- 
seum Square, Cluj-Napoca, Romania. In: Ilovan O.-R., Dulamă M. E. (eds.): Territorial Identity and Values in Geographical Education. Cluj-Napoca: Presa Universitară Clujeană, pp. 59-118.

European Commission (2013): Quality of Life in Cities. Perception Survey in 79 European Cities. Regional and Urban Policy. Luxembourg: Publications Office of the European Union. https://doi.org/10.2776/79403.

GAAL G. (2005): Magyarok utcája. A kolozsvári egykori Bel- és Külmagyar utcák, telkei, házai, lakói [The Hungarian Street. Houses, Plots and Inhabitants of the Former Intra and Extramuros Hungarian Streets in Cluj-Napoca]. Kolozsvár: Az Erdélyi Múzeum-Egyesület kiadása.

Gallion A. B., Eisner S. (1980): The Urban Pattern: City Planning and Design. New York: D. van Nostrand Company.

Garner B. (1972): Models of Urban Geography and Settlement Location. In: ChORLey R. J., HaGGETT P. (eds.): Socio-Economic Models in Geography. London: Methuen, pp. 303-355.

GeHL J. (2011): Life Between Buildings. Using Public Space. London: Island Press.

Gehl J., Svarre B. (2015): Cum se studiază viața urbană [The Way to Study Urban Life]. București: Igloomedia.

Ghavampour E. (2014): The Contribution of Natural Design Elements to the Sustained Use of Public Space in a City Centre. A thesis submitted to the Victoria University of Wellington in fulfilment of the requirements for the degree of Doctor of Philosophy in Architecture. Wellington: Victoria University of Wellington, New Zealand. - available at file: ///C:/Users/TID/ Downloads/ thesis.pdf (accessed on February 5, 2018).

Giroto I. R. (2013): A praça e o povo. Arquitetura de Fábio Penteado [The Square and the People. Architecture of Fábio Pentrado]. Seminário Nacional DOCOMOMO Brasil - Interdisciplinaridade e experiências em documentação e preservação do patrimônio recente. - http:// docomomo.org.br/wp-content/uploads/2016/01/019_M13_RM-ArquiteturaParaA Multidao-ART_ivo_giroto.pdf (accessed on February 5, 2018).

GrandPIERRE E. (1987): A kolozsvári Szent Mihály-templom [The St. Michael's Church of Cluj]. In: BÁLINT I. J. (ed.): Kincses Kolozsvár [The Treasurable Kolozsvár]. Budapest: Kner Nyomda.

GrubBauer M. (2017): In Search of Authenticity. In: City, 21 (6), pp. 789-799. - https://doi.org/ 10.1080/13604813.2017.1412200.

Hall S. (2008): New Cultures for Old? (reprint from Doreen Massey and Pat Jess (eds): A Place in the World? Places, Cultures and Globalization, 1995). In: Oakes T. S., Price P. L. (eds.): The Cultural Geography Reader. New York: Routledge, pp. 264-274.

Hantos G. (1987): Kétvízközi majorok [The Manor Houses from the Two-Rivers District]. In: Bálint I. J. (ed.): Kincses Kolozsvár [The Treasurable Kolozsvár]. Budapest: Kner Nyomda.

HĂRMĂNESCU M., ENACHE C. (2016): Vernacular and Technology. InBetween. In: Procedia Environmental Sciences, 32, pp. 412-419.

JAKAB E. (1870): Kolozsvár története. Első kötet [The History of Cluj. First Volume]. Budapest: Magyar Király Egyetemi Könyvnyomdá.

JAKAB E. (1888): Kolozsvár története. Második kötet [The History of Cluj. Second Volume]. Budapest: Magyar Király Egyetemi Könyvnyomdá.

Kelemen L. (1987): A Bánffy-palota [The Bánffy Palace]. In: BÁLINT I. J. (ed.): Kincses Kolozsvár [The Treasurable Kolozsvár]. Budapest: Kner Nyomda.

Korcelli-OlejniczaK E. (2015): On City-Region Relations. Towards the Urban-Rural Region of Warsaw. In: Mitteilungen der Österreichischen Geographischen Gesellschaft, 157, pp. $129-149$.

Lerner J. (2014): Urban Acupuncture: Celebrating Pinpricks of Change that Enrich City Life. Washington DC: Island Press. 
LMI - Lista Monumentelor Istorice [List of Historical Monuments] (2015). Ministerul Culturii, anexă la Ordinul Ministrului Culturii Nr. 2.828/2015. - http://patrimoniu.gov.ro/images/lmi2015/LMI-CJ.pdf (accessed on February 5, 2018).

LuKÁcs J. (2005): Povestea “orașului - comoară”. Scurtă istorie a Clujului și a monumentelor sale [The Story of the "Treasure-Town". Short History of Cluj and Its Monuments]. Cluj-Napoca: Biblioteca Apostrof.

LyNCH K. (2011): A imagem da cidade [The Image of the City]. Lisboa: Edições 70.

Macartney C. A. (1962): Hungary. A Short History. Edinburgh: The Edinburgh University Press.

Maimunah R., Dasimah O., Roziah M.Y., Zalina S. (2015): Revitalization of Urban Public Spaces: An Overview. In: Procedia - Social and Behavioral Sciences, 201, pp. 360-367.

Maroşı Z. (2015): Peisaje culturale în centrul istoric al Municipiului Cluj-Napoca. Lucrare de disertație [Cultural Landscapes in the Historical Centre of Cluj-Napoca City]. Master's Thesis, Faculty of Geography, Babeș-Bolyai University, Cluj-Napoca.

Maroşı Z. (2016): Redrawing Historical Illustrations in Research of Genuine Urban Features. In: Territorial Identity and Development, 1 (1), pp. 45-58. - https://doi.org/10.23740/TID120163.

Massey D. (2008): A Global Sense of Place (reprint from Space, Place, and Gender, 1994). In: Oakes T. S., Price P.L. (eds.): The Cultural Geography Reader. New York: Routledge, pp. 257-263.

Melvin J. (2006): ...isme. Să înțelegem stilurile arhitecturale [...isms. Understanding Architectural Styles]. Bucureşti: Enciclopedia RAO.

Mishu M. R., Barua U., Stoican I.-A. (2014): The Changing Nature of Urban Public Places in Dhaka City. In: Urbanism Architecture Constructions, 5 (4), pp. 5-16.

Moldovan M., Purcar C. (2012): Piețele urbane ca peisaje. Elemente de analiză vizuală [Urban Public Spaces as Landscapes. Elements of Visual Analysis]. Cluj-Napoca: U.T. Press.

Moniturul de Cluj (2015). - http://www.monitorulcj.ro/administratie/47417-centrul-se-prabusestedoar-7-cladiri-degradate-din-1000-vor-intra-in-reparatiit\#sthash.aiQqu5io.dpbs (accessed on December 10, 2018).

NaGy P. (1926): Ó, kedves Kolozsvár [Oh, Dear Cluj]. Berlin: Ludwig Voggenreiter Verlag Magyar Osztály.

NARCiso C. A. F. (2009): Espaço público: ação política e práticas de apropriação. Conceito e procedências [Public Space: Political Action and Appropriation Practices. Concept and Origins]. In: Estudos e Pesquisas em Psicologia, 9 (2), pp. 265-291.

Nemeş A., Popa I (1960): Sistematizarea Pieței Mihai Viteazul din Cluj [Systematisation of Mihai Viteazul Square in Cluj]. In: Arhitectura R.P.R., 8 (3), pp. 38-39.

Niedermaier P. (2016): Geneza oraşelor medievale în Transilvania [The Genesis of Medieval Towns in Transylvania]. București: Editura Academiei Române.

Păcurar B. N. (2013): Pedestrianisation in Cluj-Napoca. An Economic (Re)Development Tool? In: Journal of Settlements and Spatial Planning, 4 (1), pp. 95-99.

Pailliart I. (2002): Spaţiul public și comunicarea [Public Space and Communication]. Iași: Polirom.

PASCU Ș. (1975): Istoria Clujului [History of Cluj]. Cluj-Napoca: Consiliul Popular al Municipiului Cluj.

Petrina M. (coord.) (2014): Plan Urbanistic General și Regulament Local de Urbanism Cluj-Napoca [Urban General Plan and Local Urbanism Reglementations for Cluj-Napoca]. - http://www. primariaclujnapoca.ro/userfiles/files/20150105pug/piese_scrise/RLU/Regulament\%20 Local\%20de\%20Urbanism_Cluj-Napoca.pdf(accessed on May 20, 2016).

Pop I. A., Bolovan I. (2013): Istoria Transilvaniei [The History of Transylvania]. Cluj-Napoca: Editura Eikon.

Radio Cluj (2018): - http://www.radiocluj.ro/2018/03/08/o-bucata-din-fatada-unei-cladiri-istoricedin-centrul-clujului-s-a-desprins-si-a-cazut-pe-trotuar/ (accessed on December 10, 2018). 
Raport de Activitate - Municipiul Cluj-Napoca [Activity Report - Cluj-Napoca Municipality] (2018). - https://files.primariaclujnapoca.ro/2019/01/08/Raport-2018-1.pdf (accessed on December 30, 2018).

RelPh E. (2008): Place and Placelessness. London: Sage Publishers.

Relph E. (2014): The Paradox of Place and the Evolution of Placelessness. Session 1 Keynote at the Symposium "Place \& Placelessness in the $21^{\text {st }}$ Century City" (September 2014) hosted by the UNSW Built Environment | People \& Place Research Cluster Workshop. - https://www. youtube.com/watch? $v=5 g X q k q 3 z T z k$ (accessed on February 5, 2018).

Relph E. (2016): Overview of Anti-Place Ideas. In: Placeness, Place, Placelessness. A website by Edward Relph exploring the concept of place, January 2016. - http://www.placeness.com /2016/01/ (accessed on February 5, 2018).

Rius-Ulldemolins J. (2014): Culture and Authenticity in Urban Regeneration Processes: Place Branding in Central Barcelona. In: Urban Studies, 51 (14), pp. 3026-3045. - https://doi.org/ 10.1177/0042098013515762.

Rusu V. S. (2015): Evoluția urbanistică a Clujului interbelic [The urban development of interwar Cluj]. Cluj-Napoca: Editura Academiei Române.

Sandström U. G., Angelstam P., KhaKee A. (2006): Urban Comprehensive Planning - Identifying Barriers for the Maintenance of Functional Habitat Networks. In: Landscape and Urban Planning, 75 (1-2), pp. 43-57. - https://doi.org/10.1016/j.landurbplan.2004.11.016.

SARAdj F. M. (2016): Compatible Development Solutions in the Context of Historical Settings in Iran. In: Urbanism Architecture Constructions, 7 (4), pp. 285-300.

SAUER C. (2008): The Morphology of Landscape (reprint from University of California Publications in Geography 2 (2), 1925, pp. 19-54). In: OAKes T. S., Price P. L. (eds.): The Cultural Geography Reader. New York: Routledge, pp. 96-104.

Sharma M. (2014): Architectural Design Quality in Local Authority Private Finance Initiative Sheltered Housing Projects: The Development of an Evaluation Tool. PhD Thesis, University of Northumbria. - http://nrl.northumbria.ac.uk/21596/ (accessed on February 5, 2018).

Spencer-OATey H. (2012): What Is Culture? A Compilation of Quotations. Global PAD Core Concepts. - https://warwick.ac.uk/fac/soc/al/globalpad/openhouse/interculturalskills/global_ pad_-_what_is_culture.pdf(accessed on April 15, 2016).

Szabó T. A. (1946): Kolozsvár települése a XIX. század végéig [The Development of Cluj until the Middle of the 19th Century]. Kolozsvár: Erdélyi Tudományos Intézet, Minerva Irodalmi és Nyomdai Müintézet.

VÂlceanu D.-G., Kosa R.-A., TĂMîRJan D.-G. (2014): Urban Landscape as Palimpsest. In: Urbanism Architecture Constructions, 5 (4), pp. 17-26.

Viero Crestani V., Barbosa Filho L. C. (2009): Praças públicas: origens, conceitos e funções [Public Squares: Origins, Concepts, and Functions]. In: Jornada de Pesquisa e Extensão 2009: Santa Maria, RS, Brasil: Univ. ULBRA Santa Maria, pp. 1-3. - http://www.ceap.br/ material/ MAT1511201011414.pdf (accessed on February 5, 2018).

Zukin S. (2008): Whose Culture? Whose City? (reprint from The Cultures of Cities, 1995). In: OAkes T. S., Price P. L. (eds.): The Cultural Geography Reader. New York: Routledge, pp. 431-438. 